\title{
53. COMPARISON OF THE ORIGIN AND EVOLUTION OF NORTHWEST PACIFIC GUYOTS DRILLED DURING LEG 144
}

\author{
Janet A. Haggerty ${ }^{2}$ and Isabella Premoli Silva ${ }^{3}$
}

\begin{abstract}
Five northwest Pacific guyots were drilled during Leg 144. Drilling results indicate that carbonate platforms grew atop volcanic edifices produced by two pulses of volcanism associated with hotspots. The first pulse of volcanism, during BarremianAlbian time, constructed the MIT and Takuyo-Daisan edifices and the pedestals of Lo-En and Wodejebato guyots, and was widespread at abyssal locations. A second pulse of volcanism, mainly across the Santonian/Campanian boundary, created emergent islands in the northern Marshall Islands and Line Islands. Eruptions during the younger portion of this second episode formed some of the southern Marshall Islands chain, including Limalok Guyot.

Independent of their age of formation, most of the volcanic islands developed weathering profiles (including soils) and forests. Two to seven million years after an island formed, its edifice was flooded and a carbonate platform began. These carbonate platforms responded to a complex function of sea-level fluctuations and environmental changes.

Shallow-water sedimentation on Leg 144 platforms terminated either in Albian, late Maastrichtian, or middle Eocene time. Their termination was not a simple mid-Cretaceous drowning event. When the northward motion of the Pacific Plate brought the platforms into the zone of equatorial upwelling, this apparently inhibited carbonate production, enhanced bioerosion, and the platforms died.

Modern Pacific atolls are an inadequate analog for these ancient Pacific platforms. The Cretaceous and Eocene carbonate platforms resembled modern carbonate banks, rather than modern atolls that have a coral-algal reef framework surrounding a lagoon. These Cretaceous and Eocene platforms produced vast quantities of loose carbonate sediment in large shoal deposits. Cretaceous rudist-algal-coral boundstones formed relatively thin bioherms associated with shoals; this association built periplatform ridges near the summit margins.
\end{abstract}

\section{INTRODUCTION}

Leg 144 investigated five northwest Pacific flat-topped seamounts (guyots of Hess, 1946) that were previously thought to be drowned atolls on the basis of seismic profiles, side scan sonar, and shallow-water limestones dredged from them. This expedition was conducted in conjunction with Leg 143, whose focus was primarily on Allison and Resolution guyots, in the Mid-Pacific Mountains (Sager, Winterer, Firth, et al., 1993). Leg 144 drilled Limalok (Site 871), Lo-En (Site 872), and Wodejebato (Sites 873-877) guyots in the Marshall Islands chain, MIT Guyot (Site 878), a feature midway between the Marshall Islands and Japan, and Takuyo-Daisan Guyot (Sites 879-880) in the Japanese Seamount Province (Fig. 1). Drilling on these five guyots during Leg 144 recovered (1) shallow-water limestones, which were expected to record relative sea-level changes; and (2) the volcanic substrate of the limestone, whose magnetic signature and geochemical composition were expected to register the paleolatitude of formation and inscribe part of the geochemical history of the DUPAL-SOPITA isotopic anomaly. Pelagic sediments overlying these deposits were expected to record paleoceanographic changes and events following the demise of these platforms.

This chapter focuses on Leg 144 shipboard and shore-based studies of the initial stage of post-cruise science. We attempt to integrate various types of studies and data to give an overview of similarities and differences in the origin and evolution of these guyots.

\footnotetext{
${ }^{\text {t}}$ Haggerty, J.A., Premoli Silva, L., Rack, F., and McNutt, M.K. (Eds.), 1995. Proc. ODP, Sci. Results, 144: College Station, TX (Ocean Drilling Program).

${ }^{2}$ Department of Geosciences, University of Tulsa, 600 South College Avenue, Tulsa, OK 74104, U.S.A.

${ }_{3}$ Departimento di Scienze della Terra, Università di Milano, Via L. Mangiagalli 34, I-20133 Milano, Italy.
}

\section{BACKGROUND}

The ocean floor of the western Pacific has numerous scattered seamounts and atolls that (1) are assembled in groups to form larger complexes, (2) are roughly organized along a preferential direction to form a chain, or (3) are isolated features. Limalok, Lo-En, and Wodejebato guyots, drilled on Leg 144, are located in the group of islands and seamounts composing the Marshall Islands. This complex group of islands and seamounts can be divided into three parts. The easternmost volcanic edifices are the Ratak Chain, which extends from Limalok Guyot to Woden-Kopakut Guyot. More centrally located edifices are in the Ralik chain; it extends from Jalwoj Atoll to Lewa Guyot and contains Wodejebato Guyot. The western edifices form an elongated cluster centered about Ujlan and Anewetak atolls; this third area contains Lo-En Guyot. The other two guyots drilled on Leg 144 are MIT Guyot, a feature midway between the Marshall Islands and Japan, and Takuyo-Daisan Guyot, part of the Seiko cluster within the Japanese Seamount Province.

Many Pacific seamounts have a flat top and lie at depths between 1000 and $2000 \mathrm{~m}$. Hess (1946) documented 160 of these features in the western Pacific when he defined the term guyot and speculated that guyots were erosionally truncated, Precambrian volcanic islands that may lack coral reefs.

Darwin $(1837,1842)$ postulated that modern barrier reefs and atolls formed on subsiding fringing reefs. Darwin (1842) also speculated that it may be possible to develop an atoll strictly by coral-reef growth on a pre-existing level surface, such as a submerged topographic bank, with or without any subsidence, and hence, without preliminary stages of a fringing reef and a barrier reef. Darwin (1842) thought that it was unlikely that a large number of atolls in the Pacific formed strictly from submerged banks. Darwin deduced the existence of local and regional subsidence from modern atolls, but the timing and extent of subsidence were unknown. 


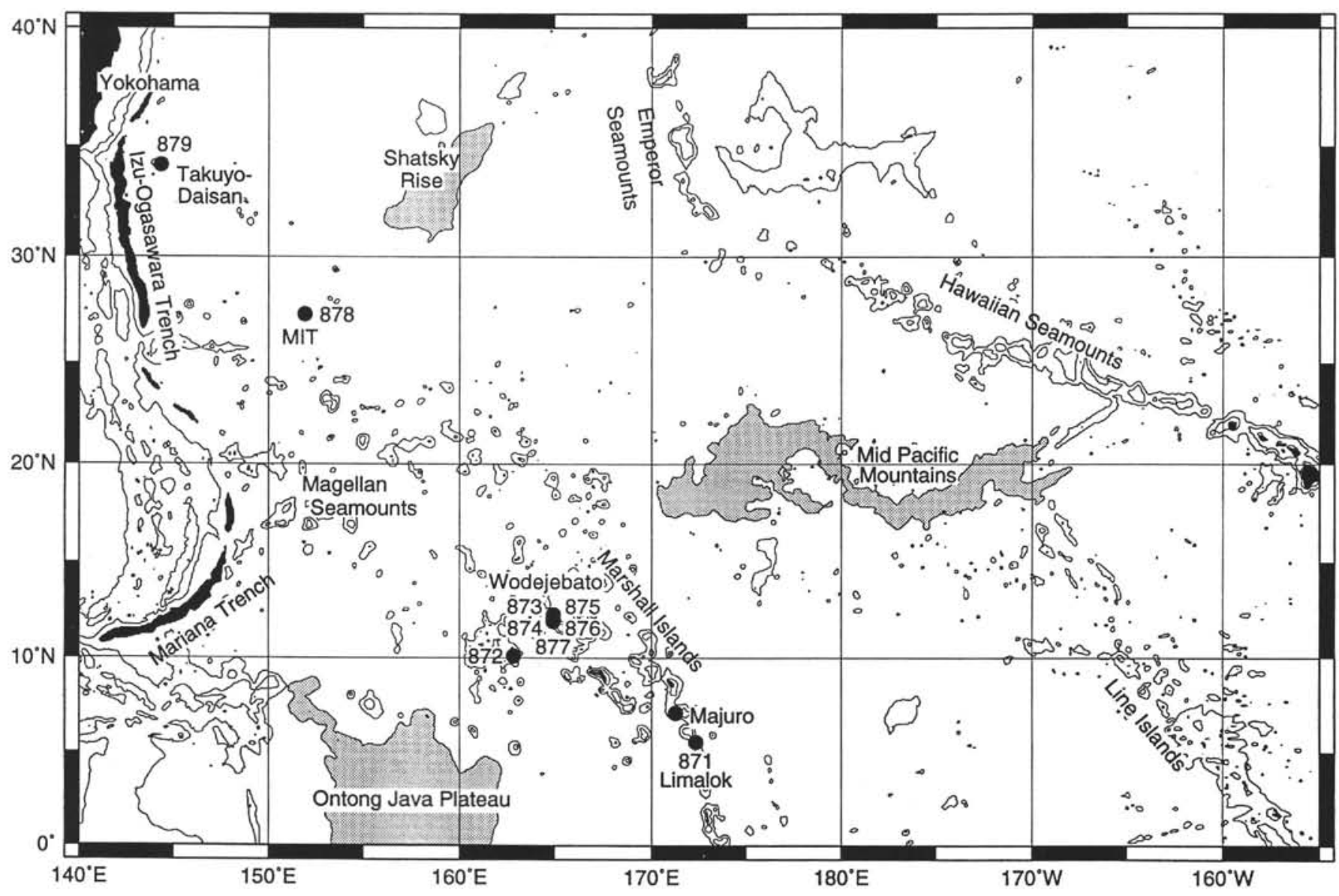

Figure 1. Location of guyots and sites drilled during Leg 144.

Hamilton (1956) reported results from a 1950 surveying and dredging expedition in the Mid-Pacific Mountains. He interpreted the results as evidence of "flat, antecedent platforms on which coral had found lodgment and might well have grown into an atoll ..." (1956, p. 50). The expedition results proved Darwin's subsidence theory and documented that Cretaceous islands and reefs existed in the Pacific basin.

\section{The Darwin Rise and the South Pacific Superswell}

Menard (1958) suggested that a mid-Pacific region, which is characterized by atolls and guyots and is more than $10,000 \mathrm{~km}$ long and $4,000 \mathrm{~km}$ wide, was previously a rise on the basis of its subsidence and its mid-basin location. In today's tectonic terminology, it would be called a midplate swell rather than a mid-ocean ridge (Menard, 1984). Menard (1964) further hypothesized that if subsidence of guyots on this rise began at (or near) sea level, then the paleobathymetry of the Pacific could be determined if these guyots were of similar age. He developed a Pacific paleobathymetric map and named this rise, which encompassed the region from the Tuamotus to the Marshall Islands, the "Darwin Rise."

Menard's paleobathymetric map is now obsolete because the underlying assumptions of unidirectional vertical motion and similar ages for the guyots were proven incorrect. Plate tectonics showed that lithospheric plate evolution played a major role in the present configuration of the Pacific Basin. Subsequent geologic expeditions proved that guyots and seamounts within the region of the Darwin Rise did not form at the same time (Fisher, Heezen, et al., 1971; Heezen et al., 1973; Winterer, Ewing, et al., 1973; Matthews et al., 1974; Larson,
Moberly, et al., 1975; Schlanger, Jackson, et al., 1976; Ozima et al., 1977; Larson, Schlanger, et al., 1981; Schlanger et al., 1984; Moberly, Schlanger, et al., 1986; Lincoln et al., 1993; Pringle, 1993; Pringle and Dalrymple, 1993; Winterer et al., 1993). Some seamounts and chains within the Darwin Rise region had multiple periods of volcanism (Haggerty et al., 1982; Schlanger et al., 1984; Lincoln et al., 1993).

The origin and evolution of seamounts, islands, atolls, and guyots as linear, clustered, and isolated features in the Darwin Rise region are still debated. The hotspot theory (Wilson, 1963; Morgan 1972a, $1972 \mathrm{~b}$ ) is the most widely accepted theory for the evolution of island and seamount chains, although some of these features require passage of the region over multiple hotspots (Schlanger et al., 1984; Lincoln et al., 1993). Thermal rejuvenescence of oceanic crust related to midplate volcanism (Crough, 1978; Detrick and Crough, 1978) complicates the story by causing uplift of the seafloor. Consequently, the seafloor in this region does not simply follow a Parsons-Sclater (Parsons and Sclater, 1977) type of subsidence path.

The term Darwin Rise and the hypothesis of its formation remained active in the literature. The postulated history of the feature required eruption of abyssal flood basalts in Cretaceous time (Menard, 1964) to explain burial of abyssal hills associated with Cretaceous seamounts. These flood basalts, as well as massive sills, were discovered by the Leg 61 expedition of the Deep Sea Drilling Project (Larson and Schlanger, 1981).

Schlanger and Premoli Silva (1981) revitalized the hypothesis of the Darwin Rise as a midplate swell. McNutt and Fisher (1987) proposed that the seafloor swell in the region of the Marshall Islands can be traced back to the active South Pacific Superswell. The South Pa- 
Table 1. Plate age of guyots drilled during Leg 144.

\begin{tabular}{lcc}
\hline Leg 144 guyots & Magnetic anomaly & Plate age (Ma) \\
\hline Limalok & M22 & $148.1-150.4$ \\
Lo-En & Jurassic Quiet Zone & Older than 156.9 \\
Wodejebato & Jurassic Quiet Zone & Older than 156.9 \\
MIT & M29 & $156.3-156.9$ \\
Takuyo Daisan & M16 & $137.9-140.4$ \\
\hline
\end{tabular}

Notes: Magnetic anomaly data from Nakanishi et al. (1992). Plate ages from Gradstein et al. (1994).

Table 2. Ages of volcanism of western Pacific guyots, seamounts, and atolls.

\begin{tabular}{|c|c|c|c|}
\hline Location & Age (Ma) & Type & Source \\
\hline $\begin{array}{l}\text { Look Guyot: } \\
12.1^{\circ} \mathrm{N}, 166.2^{\circ} \mathrm{E}\end{array}$ & $139.0 \pm 0.4(138.0 \pm 0.4)$ & ${ }^{40} \mathrm{Ar} /{ }^{39} \mathrm{Ar}$ & 1 \\
\hline $\begin{array}{l}\text { MIT Guyot: } \\
\text { Site } 878\end{array}$ & $\begin{array}{l}124.5 \pm 0.9(122.9 \pm 0.9) \\
123.3 \pm 1.6(121.7 \pm 1.6) \\
121.3 \pm 0.7(119.6 \pm 0.7)\end{array}$ & $\begin{array}{l}{ }^{40} \mathrm{Ar} r^{39} \mathrm{Ar} \\
{ }^{40} \mathrm{Ar} /^{39} \mathrm{Ar} \\
{ }^{40} \mathrm{Ar} /{ }^{39} \mathrm{Ar}\end{array}$ & $\begin{array}{l}2 \\
2 \\
2\end{array}$ \\
\hline $\begin{array}{l}\text { Takuyo-Daisan Guyot: } \\
\text { Site } 879 \\
\text { Dredge haul }\end{array}$ & $\begin{array}{c}\text { late Aptian } \\
119.0 \pm 1.8(118.4 \pm 1.8)\end{array}$ & ${ }^{40} \mathrm{Fossil}$ & $\begin{array}{l}3 \\
2\end{array}$ \\
\hline $\begin{array}{l}\text { Takuyo-Daini Seamount: } \\
\text { Seiko Cluster }\end{array}$ & $118.6 \pm 1.1(118.1 \pm 1.1)$ & ${ }^{40} \mathrm{Arr} /{ }^{39} \mathrm{Ar}$ & 2 \\
\hline $\begin{array}{l}\text { Lo-En Guyot: } \\
\text { Dredge haul } \\
\text { Site } 872\end{array}$ & $\begin{array}{c}\text { Albian } \\
114.5 \pm 1.2(112.8 \pm 1.2) \\
\text { Campanian? }\end{array}$ & 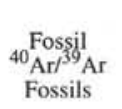 & $\begin{array}{l}1 \\
2 \\
5\end{array}$ \\
\hline $\begin{array}{l}\text { Mij-Lep Guyot: } \\
7.0^{\circ} \mathrm{N}, 163.0^{\circ} \mathrm{E}\end{array}$ & $110^{*}$ & ${ }^{40} \mathrm{Ar} /{ }^{39} \mathrm{Ar}$ & 4 \\
\hline $\begin{array}{l}\text { Lewa Guyot: } \\
13.94^{\circ} \mathrm{N}, 163.08^{\circ} \mathrm{E}\end{array}$ & Albian & Fossil & 1 \\
\hline $\begin{array}{l}\text { Lobbadede Guyot: } \\
13.8^{\circ} \mathrm{N}, 163.6^{\circ} \mathrm{E}\end{array}$ & $\begin{array}{c}\text { Albian } \\
83.5 \pm 2.4(82.4 \pm 2.4)\end{array}$ & ${ }^{40} \mathrm{Ar}^{39} \mathrm{Ar}$ & $\begin{array}{l}1 \\
1\end{array}$ \\
\hline $\begin{array}{l}\text { Ruwituntun Guyot: } \\
11.8^{\circ} \mathrm{N}, 167.0^{\circ} \mathrm{E}\end{array}$ & $\begin{array}{c}\text { Albian } \\
\text { Campanian }\end{array}$ & $\begin{array}{l}\text { Fossil } \\
\text { Fossil }\end{array}$ & $\begin{array}{l}1 \\
1\end{array}$ \\
\hline $\begin{array}{l}\text { Wodejebato Guyot: } \\
12.0^{\circ} \mathrm{N}, 164.9^{\circ} \mathrm{E} \\
\text { Site } 869 \\
\text { Site } 877 \\
\text { Sites } 873,874,876\end{array}$ & $\begin{array}{c}\text { Albian ? } \\
95.7 \pm 0.3(94.4 \pm 0.3) \\
\text { Cenomanian } \\
84.4 \pm 1.1(83.2 \pm 1.1)\end{array}$ & $\begin{array}{l}\text { Fossil } \\
{ }^{40} \mathrm{Ar} /{ }^{39} \mathrm{Ar} \\
{ }_{\mathrm{Fossil}} \\
{ }^{40} \mathrm{Ar} /{ }^{39} \mathrm{Ar}\end{array}$ & $\begin{array}{l}1 \\
2 \\
3 \\
2\end{array}$ \\
\hline $\begin{array}{l}\text { Lokkworkwor Seamount: } \\
8.9^{\circ} \mathrm{N}, 169.8^{\circ} \mathrm{E}\end{array}$ & $86.7-87.9^{*}$ & ${ }^{40} \mathrm{Ar} /{ }^{39} \mathrm{Ar}$ & 4 \\
\hline $\begin{array}{l}\text { North Wod-En Seamount: } \\
15.0^{\circ} \mathrm{N}, 162.9^{\circ} \mathrm{E}\end{array}$ & $86.5 \pm 0.4(8.5 .3 \pm 0.4)$ & ${ }^{40} \mathrm{Ar} /{ }^{39} \mathrm{Ar}$ & 1 \\
\hline $\begin{array}{l}\text { Likelep Seamount: } \\
10.6^{\circ} \mathrm{N}, 160.4^{\circ} \mathrm{E}\end{array}$ & $83.2 \pm 0.7(82.1 \pm 0.7)$ & ${ }^{40} \mathrm{Ar} /{ }^{39} \mathrm{Ar}$ & 1 \\
\hline $\begin{array}{l}\text { Woden-Kopakut Guyot: } \\
14.0 \mathrm{~N}, 167.5 \mathrm{E}\end{array}$ & $83.8-80.6^{*}$ & ${ }^{40} \mathrm{Ar} /{ }^{39} \mathrm{Ar}$ & 4 \\
\hline Anewetak Atoll & $76.9 \pm 0.6(75.9 \pm 0.6)$ & ${ }^{40} \mathrm{Ar} /{ }^{39} \mathrm{Ar}$ & 1 \\
\hline $\begin{array}{l}\text { Limalok Guyot: } \\
\text { Site } 871\end{array}$ & early late Paleocene & Fossil & 3 \\
\hline
\end{tabular}

Notes: Locations given in longitude and latitude are dredge hauls; otherwise, as indicated. Converted ages are according to the time scale of Gradstein et al. (1994), which was used as the standard time scale for this volume (see Erba et al., this volume); radiometric ages in parentheses are according to the source cited. Single asterisk $\left(^{*}\right)$ indicates that the radiometric ages are from the following sources: $1=$ Lincoln et al (1993), 2 = Pringle and Duncan (this volume), 3 = Premoli Silva, Haggerty, Rack, et al. (1993), $4=$ Davis et al. (1989), and $5=$ this study.

cific Superswell is characterized by the numerous volcanic island chains that formed as intraplate volcanoes related to several hotspots in the region. This region has an unusually weak or thin lithosphere with potentially enhanced small-scale convection from regional mantle upwelling. More recent work also describes this region with the term SOPITA: South Pacific Isotopic and Thermal Anomaly (Smith et al., 1989; Staudigel et al., 1991). McNutt and Fisher (1987) also commented on the similarity between morphologic and petrologic characteristics of the South Pacific Superswell and the mid-Cretaceous Darwin Rise; they proposed that the South Pacific Superswell is the modern equivalent of the Darwin Rise. Further, McNutt et al. (1990) discussed the specific issue of the Darwin Rise as a Cretaceous superswell.

\section{DRILLING OBJECTIVES}

Seismic profiles of Limalok, Lo-En, and Wodejebato guyots drilled during Leg 144 exhibited well-developed sedimentary caps, previously interpreted as pelagic sediment deposited after the atoll drowned. In addition to recovery of the carbonate platform and igneous basement, recovery of the pelagic cap on these guyots was planned for the following objectives: 1) high-resolution stratigraphy and to reconstruct the paleoceanography of the area; 2 ) to relate the acoustic stratigraphy of the pelagic cap to its depositional and diagenetic history and correlate seismic reflectors regionally among other guyots; and 3) to date the interface between the pelagic cap and the underlying platform, in order to infer the age and cause of platform drowning. Results pertaining to these objectives are covered in Israelson et al. (this volume), Pearson (this volume), Rack et al. (this volume), and Watkins et al. (this volume).

Drilling of all five guyots on Leg 144 had the following objectives: (1) to establish the stratigraphy, examine the faunas, floras, and growth history of the carbonate platform, and interpret the facies changes with time; (2) to reconstruct migration routes of benthic organisms and consider their paleoceanographic implications; (3) to examine the diagenesis of the shallow-water limestones and compare the diagenesis of the older guyots with the younger guyots; (4) to investigate the nature and variability of perimeter ridges on Wodejebato and Takuyo-Daisan guyots; (5) to determine the age and causes of platform drowning, possible emergence, and subsidence history of the platform limestones relative to sea level; (6) to determine the genesis of the rough surface topography of MIT and Takuyo-Daisan guyots in relation to the hypothesis of emergence and formation of karst topography on the shallow-water limestone caps before final drowning; (7) to establish the age and paleolatitude of the volcanic edifices at the time of their formation, and subsequent changes in paleolatitude; (8) to obtain geochemical data from the volcanic edifices for comparison with other sites and the DUPAL/SOPITA anomaly; and (9) to compare the geologic history of the drilled guyots. The results pertaining to these first eight objectives are covered in other specialty chapters and synthesis chapters in this volume. Results that bear on the last objective, a comparison of the geologic history of the drilled guyots, are the primary focus of this paper.

\section{VOLCANISM OF GUYOTS IN THE NORTHWEST PACIFIC}

The Pacific Plate underlying the Leg 144 guyots formed primarily during Late Jurassic time, as indicated by the surrounding magnetic lineations and magnetic quiet zone (see site map preceding the title page; Table 1). Only at Takuyo-Daisan Guyot is the plate-age younger; the identified magnetic lineation there is M16, of earliest Cretaceous age (Table 1).

The radiometric ages of the guyots presented in this section and Table 2 are from various sources. Radiometric ages determined by Pringle and Duncan (this volume) and Pringle for Lincoln et al. (1993) are converted to the Gradstein et al. (1994) time scale, which was used as a standard for this volume (see Erba et al., this volume).

Leg 144 guyots and those nearby in the northwest Pacific formed significantly later than the crust (Table 2). Look Guyot, in the Marshall Islands, is the only guyot where there is evidence of Early Cre- 
Table 3. Ages of volcanism at basinal western Pacific drill sites.

\begin{tabular}{|c|c|c|c|}
\hline Location & Age (Ma) & Type & Source \\
\hline $\begin{array}{l}\text { Pigafetta Basin: } \\
\text { ODP Site } 800 \\
\text { ODP Site } 801\end{array}$ & $\begin{array}{l}127.7(126) \\
\text { Barremian-late Aptian } \\
\text { late Aptian-Cenomanian? }\end{array}$ & $\begin{array}{l}{ }^{40} \mathrm{Ar} /^{39} \mathrm{Ar} \\
\text { Fossil } \\
\text { Fossil }\end{array}$ & $\begin{array}{l}1 \\
2 \\
2\end{array}$ \\
\hline $\begin{array}{l}\text { East Mariana Basin: } \\
\text { ODP Site } 802 \\
\text { DSDP Site } 585\end{array}$ & $\begin{array}{c}\qquad 16.6(115) \\
\text { late Aptian } \\
\text { late Aptian-early Albian }\end{array}$ & $\begin{array}{l}{ }^{40} \mathrm{Ar} /{ }^{39} \mathrm{Ar} \\
\text { Fossil } \\
\text { Fossil }\end{array}$ & $\begin{array}{l}1 \\
1 \\
3\end{array}$ \\
\hline $\begin{array}{l}\text { Nauru Basin: } \\
\text { DSDP Site } 462\end{array}$ & $\begin{array}{c}108.5-114.6(107-113) \\
69.5\end{array}$ & $\begin{array}{l}{ }^{40} \mathrm{Ar} /{ }^{39} \mathrm{Ar} \\
{ }^{40} \mathrm{Ar} /{ }^{39} \mathrm{Ar}\end{array}$ & $\begin{array}{c}3,4 \\
5\end{array}$ \\
\hline
\end{tabular}

Notes: Radiometric ages have been converted to the time scale of Gradstein et al. (1994), which was used as the standard time scale for this volume (see Erba et al. this volume). Ages in parentheses have been taken from the following sources: $1=$ Pringle (1992), 2 = Larson, Lancelot, et al. (1992), 3 = Moberly, Schlanger, et al. (1986), 4 = Ozima et al. (1981), and $5=$ this study.

taceous volcanism. Alkalic basalt dredged from this guyot is dated as $139 \mathrm{Ma}$ (Lincoln et al., 1993).

MIT Guyot has evidence of Barremian to early Aptian volcanic activity. A 200-m-thick section of volcanogenic polymictic breccia is sandwiched between two carbonate platforms. Clasts of hawaiites from this breccia, and hawaiite from the parental lava sequence of the upper volcanic edifice, are radiometrically dated as $121.3 \mathrm{Ma}$ (Pringle and Duncan, this volume). Basanites and alkalic basalts erupted at 123.3 and 124.5 Ma, respectively (Pringle and Duncan, this volume) thus preceding the hawaiites.

A wide-spread pulse of regional volcanism constructed a number of edifices during the mid-Cretaceous. This late Aptian to early Albian event is documented by radiometric dating of plagioclase separates from basalt dredged at Takuyo-Daini Guyot as $118.6 \mathrm{Ma}$ and alkalic basalt drilled at Lo-En Guyot as 114.5 Ma (Pringle and Duncan, this volume); basalt dredged at Mij-Lep Guyot is $110 \mathrm{Ma}$ (Davis et al., 1989). Albian or older volcanism formed Lewa, Lobbadede, Lo-En, and Ruwituntun guyots; this interpretation is based upon Albian fossil ages derived from shallow-water or near-shore limestones dredged from these features (Lincoln et al., 1993).

Cenomanian or older volcanism formed Wodejebato Guyot. Reworked Cenomanian nannofossils were recovered from the summit at Site 877 (Premoli Silva, Haggerty, Rack, et al., 1993). In addition, Albian? rudists were dredged from the southwest flank (Lincoln et al., 1993). The interpretation of a Cenomanian or older volcanic event at Wodejebato Guyot is also supported by radiometric dates of material recovered at Site 869 in the archipelagic apron of Wodejebato Guyot. Plagioclase-phyric clasts and hawaiites sampled from volcaniclastic breccias are dated as 93.9 and $96.3 \mathrm{Ma}$, respectively (Pringle and Duncan, this volume).

In addition to the construction of edifices during the mid-Cretaceous, intrusions and eruptions are also documented in the abyssal plains (Table 3). Alkalic dolerite sills were intruded below the seafloor at $127.7 \mathrm{Ma}$ at Site 800 in the Pigafetta Basin, whereas at Site 802 , in the East Mariana Basin, at least $50 \mathrm{~m}$ of tholeiitic submarine lavas erupted at $116.6 \mathrm{Ma}$ (Pringle, 1992). At about $110 \mathrm{Ma}$, a period of large-scale volcanism in the Nauru Basin at Site 462 is documented by massive sheet flows, pillow basalt, and sills that are more than $700 \mathrm{~m}$ in thickness (Moberly, Schlanger, et al., 1986).

Volcaniclastic turbidites deposited in abyssal locations also document mid-Cretaceous volcanism from the Barremian to possibly Cenomanian time. At Site 800, in the Pigafetta Basin, nearby volcanism contributed to the deposition of approximately $200 \mathrm{~m}$ of volcaniclastics during the Barremian to late Aptian (Larson, Lancelot, et al., 1992). At Site 585, in the East Mariana Basin, massive volcanogenic turbidites, at least $300 \mathrm{~m}$ in thickness, were deposited during the late
Aptian to early Albian time (Moberly, Schlanger, et al., 1986). These turbidites attest to the presence of nearby volcanic features supporting shallow-water reefs on the basis of the shallow-water carbonate debris concentrated in the basal portions of some turbidites (Haggerty and Premoli Silva, 1986). At Site 801, also in the Pigafetta Basin, nearby volcanism supplied approximately $200 \mathrm{~m}$ of volcaniclastic turbidites during the late Aptian to possibly Cenomanian time. Four cores at the base of these volcaniclastic turbidites did not contain agediagnostic fossils and therefore these deposits may be older than late Aptian (Larson, Lancelot, et al., 1992).

A second pulse of volcanism associated with the Marshall Islands region occurred in the Late Cretaceous (Table 2). The earliest Late Cretaceous volcanism, documented on Lokkworkwor and North Wod-En seamounts, is dated as $87.3 \mathrm{Ma}$ (Davis et al., 1989) and as 86.5 Ma (Lincoln et al., 1993), respectively. Other Late Cretaceous radiometric ages are recorded at Likelep Seamount (83.2 Ma; Lincoln et al., 1993), Lobbadede Guyot (83.5 Ma; Lincoln et al., 1993), and Woden-Kopakut Guyot (approximately $82 \mathrm{Ma}$; Davis et al., 1989).

At Wodejebato Guyot, three of the five drill sites provided suitable material from the upper volcanic edifice for radiometric dating. The dating yielded ages at about $84.4 \mathrm{Ma}$ (Pringle and Duncan, this volume), for a sample associated with a magnetic reversal interval interpreted as magnetic chron 33R (Gee and Nakanishi, this volume). The radiometric ages of the upper volcanic substrate from Wodejebato provide evidence of a second volcanic event on this guyot.

Lo-En Guyot also has evidence for a second event of volcanism. In Hole $872 \mathrm{~B}$, Campanian pelagic sediments contained palagonitized glass shards. The interpretation of a volcanic event younger than $114.5 \mathrm{Ma}$ is also supported by the presence of volcanic cones on the guyot, which extend through, and are exposed above the pelagic cap (Premoli Silva, Haggerty, Rack, et al., 1993). The upper basalt of the edifice of Anewetak Atoll, the living sibling of Lo-En Guyot, is dated as $76.9 \mathrm{Ma}$ (Lincoln et al., 1993).

The youngest Cretaceous radiometric age for basalt in the Marshall Islands area is $69.5 \mathrm{Ma}$. This age determination is from hornblende crystals in redeposited volcanic material from the Nauru Basin at Site 462 (Pringle, pers. comm.), near Limalok Guyot. This Late Cretaceous age may represent the age of the Limalok volcanic edifice; at Site 871 , the oldest recovered nannofossils that overlie the weathered volcanic basement are early late Paleocene.

In summary, a range of Early through mid-Cretaceous volcanism formed guyots over a vast area of the northwest Pacific. Mid-Cretaceous volcanism in the northwest Pacific is more intense and widespread, both in terms of guyot formation and in basinal activity than the Early Cretaceous volcanism, although this conclusion may be based on incomplete sampling. A period of Late Cretaceous volcanism is prevalent in the Marshall Islands area. In addition, at least three guyots in the Marshall Islands area had both mid- and Late Cretaceous volcanism.

\section{HOTSPOTS}

Davis et al. (1989) and Lincoln et al. (1993) contended that a single hotspot model cannot explain the origin and evolution of the Marshall Islands. A simple linear age progression is disputed by the observation that younger edifices lie north of older edifices for the Ratak and Ralik chains in the Marshall Islands (Davis et al., 1989). Lincoln et al. (1993) documented four locations in the Marshall Islands area where either volcanism or reef-building occurred in the Late Cretaceous on the basis of radiometric and fossil-age data from dredged rocks. In each case, either the same location or an immediately adjacent one also had Early Cretaceous volcanism or reef-development. Lincoln et al. (1993) interpreted the superposition of ages to indicate that the Marshall Islands area was formed by more than one hotspot. 
The currently active hotspots in the French Polynesia area are within SOPITA and are related to the South Pacific Superswell (McNutt and Fisher, 1987). In contrast to the Hawaiian hotspot, none of the hotspots within the French Polynesian area produces large volumes of magma; only small islands are formed. Also, the French Polynesian volcanoes do not exhibit a simple age progression because the multiple hotspots of the SOPITA area produce discontinuous and spatially dispersed volcanic activity (Chauvel et al., 1992). Rejuvenescent volcanism caused by another hotspot was documented by Turner and Jarrard (1982) in the Austral-Cook chain of the South Pacific Superswell; overprinting may explain the observed transposition of ages in that region, as well as in the Marshall Islands region.

A portion of the upper volcanic edifice was recovered from each of the Leg 144 guyots. Most of these lavas underwent extensive lowtemperature alteration. The petrography and mineral chemistry indicate that these lavas are of alkalic affinity, with the exception of the lava recovered from Takuyo-Daisan Guyot, which is tholeiitic or transitional in character (Christie et al., this volume). Although the geochemical characteristics of the lavas are affected to varying degrees by the low-temperature alteration processes, the incompatibleelement ratios and relative-abundance patterns are relatively uniform. Christie et al. (this volume) and Koppers et al. (this volume) conclude that these ratios and abundance patterns, as well as the isotope geochemistry, demonstrate a strong resemblance to the currently active hotspots of the SOPITA area, especially Tahiti.

The age data (Table 2) from Leg 144 support the assertion by Davis et al. (1989) and Lincoln et al. (1993) that a single hotspot model cannot explain the origin and evolution of the Marshall Islands. The ages of the Leg 144 guyots cannot be reconciled with a simple linear age progression of younger edifices to the southeast, as would have been expected for edifices formed by passage over a single hotspot. For example, the alkalic basalt and hawaiite from the upper volcanic edifice of Lo-En Guyot (114.5 Ma) are significantly older than the alkalic basalt and hawaiite from the upper volcanic edifice of Wodejebato Guyot ( $84.4 \mathrm{Ma}$ ) to the northeast, or the basalt of the upper volcanic edifice of its living sibling Anewetak Atoll (76.9 Ma) immediately to the north-northwest. The observation that younger edifices lie north of older edifices in the Marshall Islands was already documented by Davis et al. (1989).

The results from Leg 144 indicate that at least three locations in the Marshall Islands region had more than one period of volcanism. As an outcome of drilling into these igneous edifices during Leg 144, the ages are now refined. Figure 2, modified from Lincoln et al. (1993), is used to illustrate the results from Leg 144 and the contention that the Marshall Islands region was formed by more than one hotspot.

Figure 2 shows the three Marshall Island guyots drilled on Leg 144 and Anewetak Atoll in a series of plate reconstructions. The locations of the three guyots and Anewetak Atoll in these reconstructions are based upon a plate-rotation model by R. Gordon as applied by Lincoln et al. (1993); this model is similar to the one of Duncan and Clague (1985) that used rotation poles for the Pacific Plate relative to fixed hotspots. The regions of the Macdonald, Tahiti, Rurutu, and Rarotonga hotspots in Figure 2 are defined by circles of $300-\mathrm{km}$ radius. This is the approximate area of influence for the Hawaiian hotspot as estimated by Henderson (1985).

\section{Lo-En Guyot}

The backtracked location of both Lo-En and Wodejebato guyots plot within the $300-\mathrm{km}$ radius of the Macdonald hotspot between approximately 115 and $105 \mathrm{Ma}$. This predicted location for Lo-En Guyot agrees with the $114.5 \mathrm{Ma}$ age of the upper basaltic flows drilled on this guyot during Leg 144 and the existence of near-shore Albian fossils recovered by dredging on the flank of the guyot. The backtracked location of Lo-En Guyot places the guyot beyond the influence of the Macdonald hotspot by $95 \mathrm{Ma}$; it did not move into the circle of influ- ence of the Rurutu hotspot until approximately $90 \mathrm{Ma}$. The backtracked location of Lo-En Guyot suggests that this guyot moved through the region of influence of the Rurutu hotspot and into an overlapping region with the Rarotonga hotspot at $85 \mathrm{Ma}$; it finally exited the region of the Rarotonga hotspot at approximately $74 \mathrm{Ma}$. If another period of volcanism occurred during the Campanian, or just before the Campanian (as noted by the glass shards in the drilled sediments at Site 872 and the presence of volcanic cones on the summit), then Lo-En Guyot was well within either the Rurutu or the Rarotonga hotspot region at that time.

\section{Anewetak Atoll}

The backtracked location of Anewetak Atoll essentially shadows the backtracked position of Lo-En Guyot. The only ${ }^{40} \mathrm{Ar} /{ }^{39} \mathrm{Ar}$ radiometric date that is available for the upper volcanic edifice is $76.9 \mathrm{Ma}$, which coincides with a predicted location for Anewetak near the rim of the Rarotonga hotspot region, shortly before its passing beyond the region of influence of any plotted hotspots.

\section{Wodejebato Guyot}

The backtracked location of Wodejebato Guyot from 115 through $94 \mathrm{Ma}$ is within the region of the Macdonald hotspot. This concurs with the existence of Albian? rudists dredged from the southwest flank of this guyot, the recovery of reworked Cenomanian nannofossils in the basal sediments of the inner perimeter ridge at Site 877, and the potential representative age of $95.7 \mathrm{Ma}$ derived from basalt clasts recovered at the basinal flank Site 869 . By $85 \mathrm{Ma}$, Wodejebato Guyot traveled more than half way across the area of influence of the Rurutu hotspot and then traversed an intersecting region with the Tahiti and Rarotonga hotspots until approximately $80 \mathrm{Ma}$, after which it moved beyond the influence of the plotted hotspots. The radiometric age of 84.4 Ma, determined from igneous material drilled at summit Sites 873,874 , and 876 , appears to coincide with the predicted location of Wodejebato Guyot on the intersection of the three hotspots.

\section{Limalok Guyot}

From 95 to $85 \mathrm{Ma}$, the backtracked location of Limalok Guyot moved across the Macdonald hotspot area. By 75 Ma, the backtracked position of Limalok Guyot is within the overlapping circles of influence of the Tahiti and Rurutu hotspots; by $65 \mathrm{Ma}$, it is near the edge of the Tahiti hotspot area. If the volcanic edifice of Limalok Guyot formed near one of these three hotspots, then edifice building occurred before $64 \mathrm{Ma}$. There are two lines of supportive evidence for a Cretaceous origin for this edifice. First, the oldest sediment recovered at the summit of Limalok Guyot, Site 871, is early late Paleocene. There is usually a gap of several million years in the record between the onset of marine sediment deposition and the age of the youngest basalt at the summit (see details in the following section). Second, the radiometric age of $69.5 \mathrm{Ma}$ for the hornblende crystals recovered from volcaniclastics in the Nauru Basin, Site 462 near Limalok Guyot, may be representative of the guyot's age.

Overall, the ages associated with volcanism for the three guyots and Anewetak Atoll coincide with their backtracked locations relative to the area of influence of one or more hotspots. The interpretation that rejuvenescent volcanism occurred on some of these guyots is supported by their backtracked locations associated with hotspots. Multiple volcanic events associated with an edifice in a linear island chain were also documented in the Line Islands (Haggerty et al., 1982; Schlanger et al., 1984) and the Austral chain, specifically at Rurutu Island (Turner and Jarrard, 1982).

Bergersen (this volume) aims to identify hotspot tracks through the Marshall Islands, treating the guyots as members of hotspot chains. The stage poles by Duncan and Clague (1985) and Henderson 

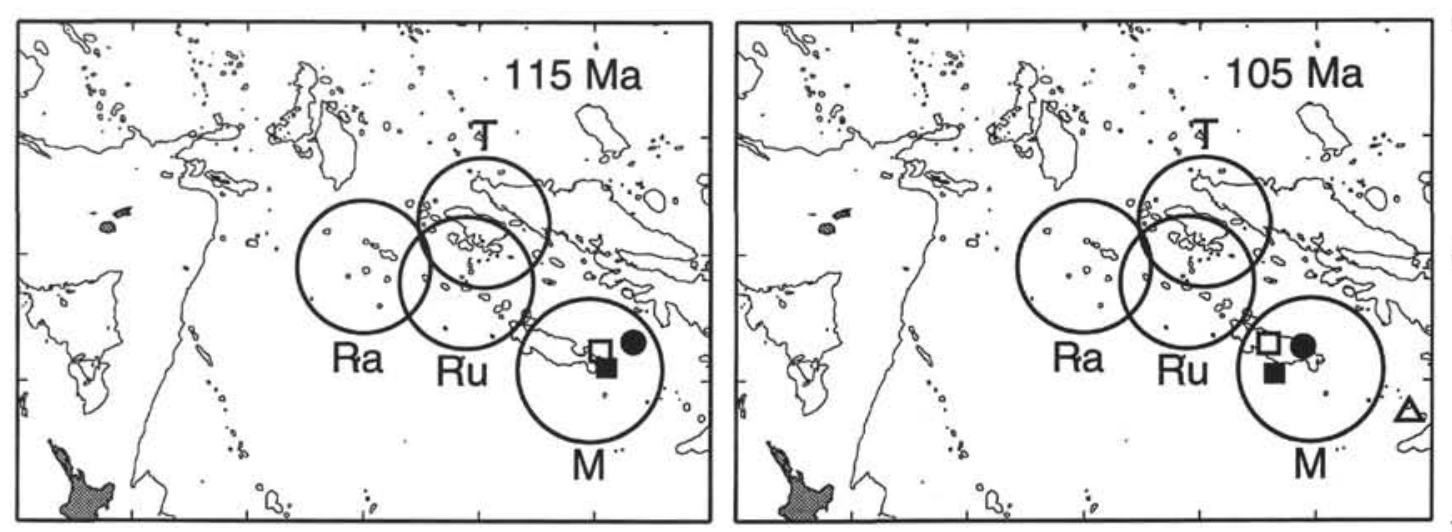

$0^{\circ}$
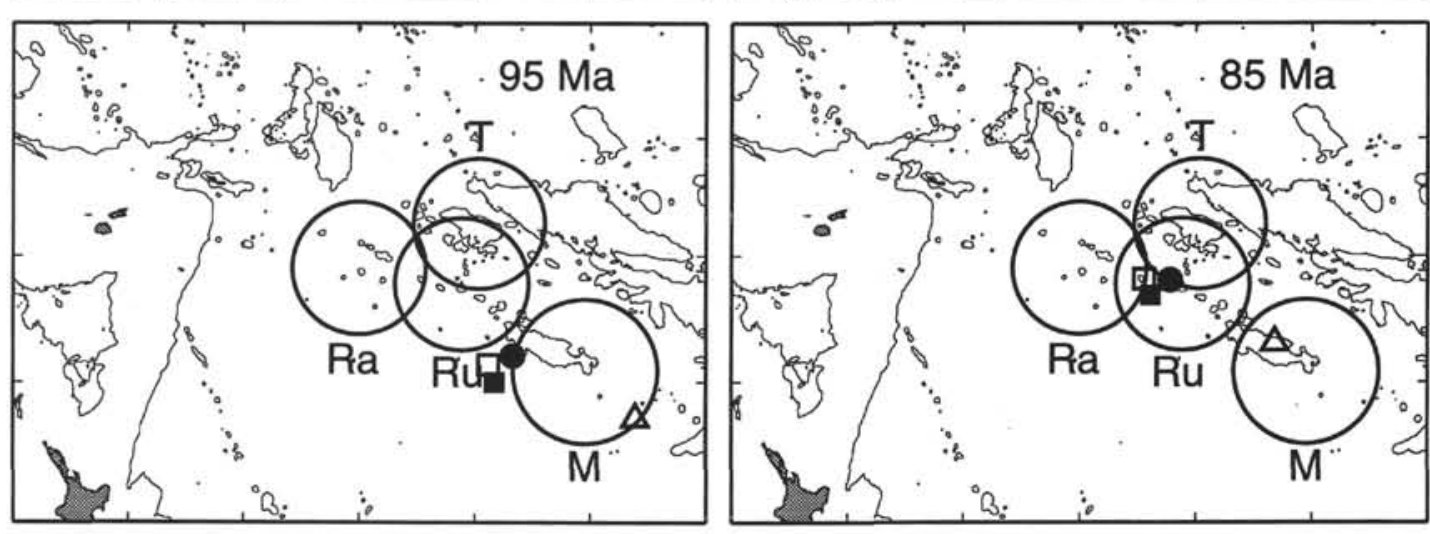

$-40^{\circ}$
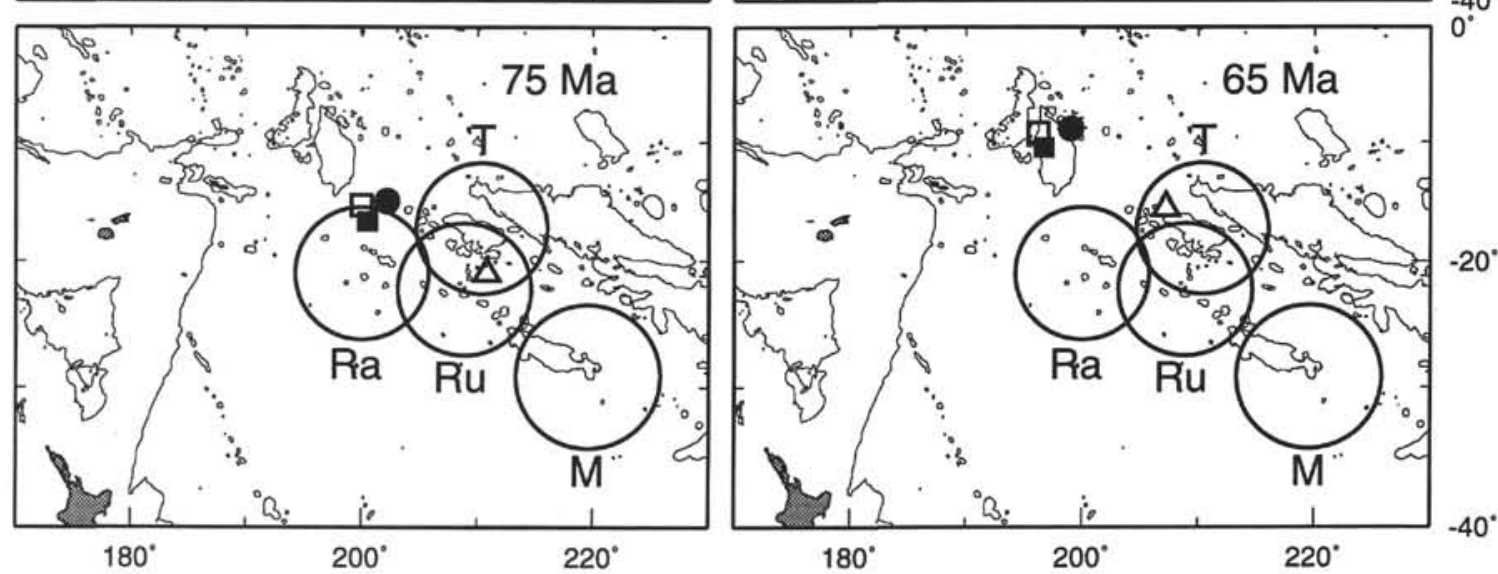

Figure 2. Time slices highlight the locations of the Leg 144 guyots in relation to the Marshall Islands. The circles represent the $300-\mathrm{km}$ radius of recently active hotspots: Macdonald $(\mathrm{M})$, Tahiti $(\mathrm{T})$, Rurutu $(\mathrm{Ru})$, and Rarotonga $(\mathrm{Ra})$. Open triangle $=$ Limalok Guyot, black circle $=$ Wodejebato Guyot, solid square $=$ Lo-En Guyot, and open square $=$ Anewetak Atoll. Figure is modified from Lincoln et al. (1993).

(1985) are used for the hypothetical hotspot tracks for Macdonald, Society (Tahiti), Rurutu, and Rarotonga as fixed hotspots from 42 to about $150 \mathrm{Ma}$.

From this exercise, Bergersen came to the following conclusions: (1) the Rurutu hotspot may be responsible for construction of most of the Ratak chain through the 74 to $100 \mathrm{Ma}$ stage pole period; (2) the 100 to 150 Ma portion of the Macdonald hotspot track crosses the northern Marshall Islands, and (3) the Ujlan-Anewetak group of edifices may be related to the Rarotonga hotspot. Bergersen's results indicate that only Rurutu, Rarotonga, and Macdonald hotspots were involved in the formation of the Marshall edifices, although a large number of edifices do not fit any of the four hotspot tracks tested.

\section{Paleolatitudes}

Shipboard and shore-based paleomagnetic measurements of the upper volcanic substrate of Limalok, Wodejebato, MIT, and TakuyoDaisan guyots reveal that the paleolatitude position of these guyots was at approximately $10^{\circ} \mathrm{S}$ at the termination of their last volcanic episode (Premoli Silva, Haggerty, Rack, et al., 1993; Nakanishi and Gee, this volume). The apparent inclination of the seamounts and their origin in the Southern Hemisphere was independently confirmed for Lo-En, Wodejebato, MIT, and Takuyo-Daisan guyots by Ito and Nogi (this volume) from downhole magnetometer logs using the Schlumberger general purpose inclinometer. 
Nakanishi and Gee (this volume) estimated the paleolatitudes of the Leg 144 guyots using the model of Duncan and Clague (1985) with fixed hotspots. The following paleolatitude estimates were calculated: Limalok Guyot at $15^{\circ} \mathrm{S}$, Lo-En Guyot at $25^{\circ} \mathrm{S}$, Wodejebato Guyot at $21^{\circ} \mathrm{S}$, MIT Guyot at $14^{\circ} \mathrm{S}$, and Takuyo-Daisan Guyot at $7^{\circ} \mathrm{S}$. Differences between the calculated and observed paleolatitudes are less than $6^{\circ}$ with the exception of Wodejebato Guyot. This difference may result from southward drift of the hotspots with respect to the paleomagnetic reference frame.

Nakanishi and Gee (this volume) also investigated the paleolatitudes of the Leg 144 guyots against the apparent polar wander paths constructed by Larson and Sager (1992). The Leg 144 guyots either did not intersect the apparent polar wander path, or the suggested ages were younger than the fossil or radiometric ages obtained for the Leg 144 guyots. The only exception was MIT Guyot where the age predicted from the apparent polar wander path without anomalous skewness is similar to the radiometric age of the guyot.

If the hotspots were fixed, the only hotspot associated with $10^{\circ} \mathrm{S}$ latitude is the Marquesas hotspot, which is not considered to be within the realm of the South Pacific Superswell. If this hotspot was involved in the origin of these features, then more of a westward component in plate motion is necessary than currently thought. If the hotspots within the South Pacific Superswell are the true origins of these volcanic edifices, then a southward drift of the hotspots is required. Several studies (Winterer et al., 1993; Gordon and Cape, 1981; Sager and Bleil, 1987) have suggested that the French Polynesian hotspots have drifted south with respect to the paleomagnetic reference frame.

The average inclination value for all five guyots helps to constrain not only the latitude of seamount formation, but also provides information about plate motion. These data may not be definitive because the shallow depths of penetration provided by drilling into the volcanic edifice may not yield an adequate number of flow units to produce a reliable time-averaged geomagnetic inclination (Nakanishi and Gee, this volume). Nakanishi and Gee (this volume) determined the reliability of the data by comparing them to paleosecular variation models.

\section{Limalok Guyot}

Paleolatitude values of Limalok and Wodejebato guyots have a directional scatter that is statistically in agreement with expected directional scatter, and therefore may have adequately averaged the paleosecular variation. Site 871, centrally located on Limalok Guyot, gave an averaged paleolatitude of $9.8^{\circ} \mathrm{S}$ during the normal polarity interval just before the late Paleocene. If the hotspots were fixed, this would place the location of Limalok edifice farther north than the Tahiti hotspot area of influence (Fig. 2).

\section{Wodejebato Guyot}

Five drill sites on Wodejebato Guyot provided a variety of volcanic material and yielded a range in the determined paleolatitudes; the average paleolatitude for the 11 flow units sampled is $8.4^{\circ} \mathrm{S}$. This average paleolatitude of $8.4^{\circ} \mathrm{S}$ would place the guyot farther north than any area of influence of the four hotspots from the South Pacific Superswell (Fig. 2), provided these hotspot have remained fixed through time.

Site 873 , centrally located on Wodejebato Guyot, yielded paleolatitudes from $9^{\circ} \mathrm{S}$ to $14^{\circ} \mathrm{S}$ from material dated at about $81 \mathrm{Ma}$. On the inner perimeter ridge, Sites 874 and 877 yielded differing paleolatitudes. Site 874 yielded a paleolatitude of $9^{\circ} \mathrm{S}$ for basalt erupted at $85.6 \mathrm{Ma}$, whereas Site 877 gave a paleolatitude of about $6^{\circ} \mathrm{S}$ for volcanic substrate that was not suitable for radiometric dating. Sites 875 and 876 , on the outer perimeter rim of Wodejebato Guyot, yielded paleolatitudes about $10^{\circ} \mathrm{S}$. The $10^{\circ} \mathrm{S}$ paleolatitude at Site 876 came from volcanic material dated as 78.6 and $82 \mathrm{Ma}$, whereas Site 875 bottomed in $9 \mathrm{~m}$ of altered basalt that was unsuitable for radiometric dating. Detailed shore-based work revealed that samples from Sites 875 and 876 contain a highly oxidized assemblage of magnesioferrite and hematite concentrated along vesicle margins and in brecciated flow tops (Gee and Nakanishi, this volume). Tests run on a few samples from Sites 875 and 876 revealed the coincidence of blocking temperature data and Curie temperatures. Gee and Nakanishi (this volume) suggest that later localized migration of fluids through flows at Sites 875,876 , and 877 may have resulted in remagnetization of portions of the volcanic units sampled.

\section{Lo-En Guyot}

We do not know the paleolatitude of the terminating volcanism on Lo-En Guyot; a paleolatitude of $31^{\circ} \mathrm{S}$ was determined for the basaltic units deposited at 114.5 Ma (Nakanishi and Gee, this volume), and coincides with its predicted location associated with the Macdonald hotspot (Fig. 2). Based upon the values determined for the expected directional scatter, the Lo-En Guyot data may not adequately provide averaged paleosecular variation.

The paleolatitude determined from drilling samples from Lo-En Guyot is significantly different from the paleolatitude of $14^{\circ} \mathrm{S}$ determined by Bryan et al. (1993) using magnetic-seamount-anomaly modeling. If the hotspots within the South Pacific Superswell are fixed, then the $14^{\circ} \mathrm{S}$ latitude may correspond to the Tahiti hotspot or the edge of influence of the Rarotonga hotspot (Fig. 2). If the rotation poles for the Pacific Plate relative to the fixed hotspot frame of reference (as used in Lincoln et al., 1993) are valid, then the edifice would not have formed until a younger age, possibly about Campanian time. Previous workers have noted that the paleolatitude determined from the drill-core samples is farther south than that derived from anomaly modeling. Gee and Nakanishi (this volume) discuss that this may be the result of significant viscous or induced magnetization.

\section{MIT Guyot}

At Site 878 on MIT Guyot, polymictic breccia was deposited at $22.2^{\circ} \mathrm{S}$ during the Aptian, although this paleolatitude may be in error because of a viscous or secondary magnetization (Nakanishi and Gee, this volume). The volcanic basement of MIT appears to have formed at $11.4^{\circ} \mathrm{S}$ during the Barremian. The $11^{\circ}$ difference in paleolatitudes is significant and difficult to reconcile with models of plate motion, such as the one of Duncan and Clague (1985). Larson et al. (1992) document southward drift of the Pacific Plate before the Hauterivian, and suggest that drift direction changed sometime between the Hauterivian and the Aptian. Plate motion may have continued in a southerly direction between the time of formation of the edifice and the polymictic breccia.

The paleomagnetic results from the drill-core samples are significantly different from the paleolatitude of $32.8^{\circ} \mathrm{S}$ calculated for MIT Guyot using sea-surface magnetic anomaly data (Sager et al., 1993). The $32.8^{\circ} \mathrm{S}$ paleolatitude agrees well with the present latitude of the Macdonald hotspot, and may agree with its Cretaceous location if the hotspots were fixed through time. The significant differences between the paleolatitudes for MIT Guyot may be the result of viscous or induced magnetization in a predominantly reversed polarity seamount (Nakanishi and Gee, this volume).

In addition, the directional scatter in the MIT Guyot data is not in statistical agreement with the expected amount of directional scatter. This may be a function of the model used for the calculation that relies on data from lavas younger than $5 \mathrm{Ma}$. The late Neogene geomagnetic field may not be an appropriate comparison if the paleosecular variation during the Cretaceous long normal was significantly lower (Nakanishi and Gee, this volume). 


\section{Takuyo-Daisan Guyot}

The paleomagnetic results from drill-core samples obtained at Site 879 on Takuyo-Daisan Guyot indicate a paleolatitude of approximately $9.9^{\circ} \mathrm{S}$ or less in late Aptian? time. The paleolatitude estimate is poorly constrained for two reasons: (1) these data are based upon a single flow unit and (2) a $10^{\circ}$ deviation from the vertical in the drill hole is not accounted for in the estimated paleolatitude. The normal polarity of Takuyo-Daisan Guyot may give paleolatitudes farther south than the $2.5^{\circ} \mathrm{N}$ paleolatitude determined by Sager et al. (1993) from sea-surface magnetic anomaly data because of a significant contribution from viscous or induced magnetization in the seamount, or partially because of the $10^{\circ}$ deviation in the drill hole.

The paleolatitudes (determined from the Leg 144 drill-core samples) of the formation of the Leg 144 volcanic edifices does not cleanly match the predicted paleolatitudes of the model presented here in Figure 2, or the model by Bergersen (this volume), or the model by Nakanishi and Gee (this volume). Most of these models assume that the hotspots are fixed and attempt to assign the formation of the volcanic edifices to the hotspots. The radiometric dates coincide with the predicted position of the guyot over a hotspot, but the predicted position does not concur with the paleolatitude determined from the drillcore samples.

There are problems determining the stage pole and angle of rotation before approximately $80 \mathrm{Ma}$. Most models infer a northwest motion of the Pacific Plate. Before $100 \mathrm{Ma}$, plate motion and hence these hotspot tracks become more speculative because no seamount chains in the Pacific basin are adequately dated beyond that age. In addition, paleomagnetic studies (Larson et al., 1992) of oceanic crust from Site 801 (northwest of the Marshall Islands; see frontispiece) indicate that the Pacific Plate drifted southward during the Late Jurassic and Early Cretaceous with about a $30^{\circ}$ clockwise rotation. The southward motion is suggested to have changed to northward motion between the Hauterivian and the Aptian. More research on plate motion is necessary to resolve these issues. A change in plate direction or rate of motion, and the possibility of hotspot wander or drift may be sufficient to explain the formation of edifices that do not currently fit hotspot models and some of the transposition of ages.

\section{PLATFORM SUBSTRATE}

Lavas and volcaniclastic sediments were recovered from the upper volcanic edifice of all five Leg 144 guyots and at nine of the ten drill sites. The lavas of the Leg 144 guyots are typically of alkalic affinity ranging from highly magnesian basanites to hawaiites (Premoli Silva, Haggerty, Rack, et al., 1993). At Takuyo-Daisan Guyot, a single tholeiitic lava was recovered (Christie et al., this volume).

The volcanic substrate, upon which the Leg 144 carbonate platforms would eventually build, underwent various forms of alteration, moderate to intense subaerial weathering, and erosion. The kaolinite concentrations typically decrease downhole as the smectite concentrations increase. Holmes (this volume) documents the moderate subaerial weathering which included dissolution or replacement of olivine, pyroxenes, and plagioclase, and alteration of glassy or aphanitic groundmass to kaolinite, smectite, goethite, and hematite. This subaerial lateritic weathering occurred in tropical to subtropical environments (Holmes, this volume), in concurrence with the paleomagnetic latitudes.

Soil development occurred on the majority of the Leg 144 guyots. Before the expedition, we did not anticipate the thickness and preservation of these soils. The recovered paleosols are $28.6 \mathrm{~m}$ thick at Site 871 centrally located on Limalok Guyot, $22.5 \mathrm{~m}$ thick at Site 873 centrally located on Wodejebato Guyot, $15 \mathrm{~m}$ thick at Site 874 and $5 \mathrm{~m}$ thick at Site 877 on the inner perimeter ridge on the summit of Wode- jebato Guyot, possibly $9.6 \mathrm{~m}$ thick at Site 878 centrally located on MIT Guyot, and $40.2 \mathrm{~m}$ at Site 879 on the southern perimeter rim of Takuyo-Daisan Guyot (Holmes, this volume).

\section{Allison and Resolution Guyots (Leg 143)}

The paleosols found on Leg 144 guyots differ in apparent thickness from those on Allison and Resolution guyots in the Mid-Pacific Mountains (Leg 143). On Resolution Guyot at Site 866, incipient weathering of the upper lava flows and volcaniclastic breccias formed clay layers; clumps of clay were recovered between flows of altered basalt. Despite the poor recovery of the clay material at Site 866 , probably as the result of being washed out during drilling, a 9$\mathrm{m}$-thick interval of volcanic breccia and clay was recovered; typically the intervals were less than one meter in thickness (Sager, Winterer, Firth, et al., 1993).

Although the apparent thicknesses of the paleosols developed on the Leg 144 guyots are significantly thicker than those from Leg 143 guyots, a kaolinite-smectite assemblage was found on both Leg 143 guyots (Murdmaa et al., this volume). The mineral assemblage is interpreted as being the product of subaerial weathering of basaltic islands that yielded immature lateritic soils in a warm tropical climate (Murdmaa et al., this volume). The same climate and weathering process occurred on these two ancient volcanic islands from the Mid-Pacific Mountains as we observed on volcanic edifices from Leg 144 guyots.

\section{Limalok Guyot}

Low-temperature alteration is pervasive throughout the lava sequence of highly alkalic basalts, basanites, and nephelinites from Site 871. Christie et al. (this volume) therefore suggest that magmatic activity continued for some time after the eruption of these flows, and consequently these flows represent a constructional phase of the edifice, rather than a low-volume, post-erosional phase.

Holmes (this volume) interpreted the subaerial weathering profile at Site 871 as possibly containing a reworked $\mathrm{A}$ horizon that overlies a mottled zone, and a pallid zone. The two lower zones, which are dominated by kaolinite, indicate a long period of subaerial weathering that probably developed under lateritic conditions in an upland plateau area, after volcanic activity ceased, while the island subsided. Holmes (this volume) also states that formation of this soil would initially require at least tens of meters of elevation in order to stand well above the water table of a subsiding island.

Terrestrial organic debris of woody tissues, plant cuticle, fungal spores, fern spores, six species of angiosperm pollen of which the most common two species are probably palm pollen, were documented in four samples of clays from 423.6 to 434.9 meters below seafloor (mbsf). No conifer pollen was present. The low taxonomic diversity of the spore and pollen assemblages suggests limited habitats for plants. The abundance of fungal spores indicated moist conditions (Premoli Silva, Haggerty, Rack, et al., 1993). The palynomorph assemblage concurs with a tropical to subtropical environment on a volcanic island.

\section{Lo-En Guyot}

Drilling at Site 872 penetrated a differentiated series of alkali basalts and hawaiites, comparable to the alkalic cap stage of Hawaiian volcanism (Christie et al., this volume). This differentiated series is probably representative of a relatively late stage in the construction of the edifice and therefore Christie et al. (this volume) conclude that deep erosion of the edifice did not occur. In Hole $872 \mathrm{C}, 10 \mathrm{~cm}$ of dark gray clay composed of smectite and feldspar overlie the basalt. This clay assemblage indicates the existence of a fresh to moderately weathered terrane (Holmes, this volume). Although several genera- 
tions of fossiliferous marine sediment infiltrated cracks in the basalt, no thick soil or weathering horizon was recovered from this guyot (Premoli Silva, Haggerty, Rack, et al., 1993). No carbonate platform was found at Site 872. Dredge hauls from this guyot recovered volcaniclastic breccia in a calcareous matrix containing shallow-water debris and planktonic foraminifers. The fossil ages and paleoecology indicate that an Albian near-shore or near-reef environment existed on Lo-En Guyot (Lincoln et al., 1993).

\section{Wodejebato Guyot (Sites 873-877)}

The seismic profile of Wodejebato Guyot reveals a relatively flat interface between the overlying carbonate platform and the steeply dipping intrabasement reflectors (Premoli Silva, Haggerty, Rack, et al., 1993). A series of differentiated alkalic basalt and hawaiite flows overlie hyaloclastite debris flow deposits and volcanogenic breccias at the bottom of the deepest penetrating hole at the centrally located Site 873 . These debris flow deposits and breccias are interpreted as being associated with a thick submarine volcaniclastic sequence (dipping reflectors) that became emergent and were overlain by a thin constructional sequence of subaerial lava flows (relatively horizontal reflectors). Christie at al. (this volume) suggest that this relatively flat feature may represent a broad coastal plain around an emergent volcano. Steeply dipping reflectors also characterize the volcanic edifices of Limalok and Lo-En guyots.

Holmes (this volume) noted that the subaerial weathering profile at the centrally located Site 873 contains a massive red clay overlying a thin, drab mottled zone, which overlies a highly reticulated claystone. The red clay is typical of tropical soils, but the drab coloration of the mottled zone indicates a lowland or poorly drained area (Holmes, this volume). The clays at Sites 874 and 877 on the inner perimeter ridge are probably the base of a soil; the surface horizons and some of the subsurface soils were eroded.

Present in the clays is terrestrial organic debris of woody tissues and plant cuticle, as well as fungal spores and fern spores (Premoli Silva, Haggerty, Rack, et al., 1993). Ferns are typically part of the pioneer community in ecologically disturbed habitats and indicate the presence of moist conditions. The fern spores dominate the assemblage from Site 874 and were found with some foraminifer linings. This combination suggests that the clay was deposited in a marginal marine setting. Holmes's (this volume) interpretation of the topography as a lowland area that was poorly drained is in agreement with the palynology and concurs with the inference made by Christie et al. (this volume) of a coastal plain setting.

\section{MIT Guyot}

At Site 878 , the basanites, alkali olivine basalts, and hawaiites represent a differentiated series of alkalic affinity (Premoli Silva, Haggerty, Rack, et al., 1993). Christie et al. (this volume) interpret these as representing the constructional phase of the volcanic edifice. Sandwiched between the two overlying carbonate sections, the polymictic breccia may represent the post-erosional phase of volcanism (Christie et al., this volume).

Only the C horizon was recovered at Site 878; it represents the deepest part of the weathering profile or alteration by ground water (Holmes, this volume).

\section{Takuyo-Daisan Guyot}

The seismic profile of Takuyo-Daisan Guyot is characterized by a sloping interface between the carbonate platform and the volcanic edifice (Premoli Silva, Haggerty, Rack, et al., 1993). Prograding reflectors dip away from a central high toward the seaward edges of the guyot. A peperite, from the base of Hole 879A in the southern perimeter rim, formed by the intrusion of lava into wet sediment. A phreatomagmatic eruption preceded the peperite formation and pro- vided host sediment for the volcanogenic breccia. An intrusion of plagioclase-phyric basalt into this breccia resulted in the formation of the peperite. The basalt is transitional or tholeiitic in character. Christie et al. (this volume) interpreted the prograding reflectors to be a volcaniclastic sequence, similar to the scenario presented for Wodejebato Guyot.

Apparently at Site 879 , only the $\mathrm{C}$ horizon was recovered, representing the deepest part of the weathering profile or alteration by ground water (Holmes, this volume).

At the top of the zone of subaerial weathering of the volcanic breccia is a $5-\mathrm{cm}$ bed of lignite, which contains abundant woody tissues and light brown resinous fragments, suggesting some thermal maturation (Premoli Silva, Haggerty, Rack, et al., 1993). The evidence for thermal maturation may be related to the intrusion of the peperite.

In the Marshall Islands region, Limalok and Wodejebato guyots had moderate to extreme subaerial weathering; Sites 871 and 873 on these two guyots displayed the most intense weathering and pedogenesis (Holmes, this volume). From the thickness of the paleosol, its mineral composition, and the absence of gibbsite, Holmes (this volume) concluded that paleosols at the centrally located Sites 871 on Limalok Guyot and 873 on Wodejebato Guyot developed in areas with less than $1 \mathrm{~m}$ of annual rainfall. She also concludes that the 12.5 $\mathrm{m}$ of soil developed at Site 871 took perhaps 1 to $3 \mathrm{~m}$.y. to form. At Sites 878 and 879 , on the basis of the lack of vertical zonation in the clay minerals, she suggests that alteration by groundwater may have occurred, or that these recovered deposits are a deep portion of the soil profile. The variation in the color, mottling, and preservation of the parent relict structure associated with the weathering and formation of clays at the Leg 144 sites is principally a function of the preservation of the soil profile.

Several of these volcanic islands became forested with ferns, possibly palms (on Limalok Guyot), and other plants. No rhyzoliths or root traces were documented in these terrestrial deposits that eventually would become the underlying substrate of the shallow-water carbonate sediments.

\section{PLATFORM INITIATION Hiatus Before Platform Initiation}

Taking into account the uncertainties and ranges in both the radiometric ages and the biostratigraphic ages correlated to an absolute time scale, there is a significant time interval between the radiometric age of the upper volcanic edifice (Table 2) and the time of deposition of the first sediments (Table 4). This interval ranges from $2 \mathrm{~m} . \mathrm{y}$. to possibly as much as $26 \mathrm{~m}$.y. Several of the guyots have a hiatus of 7 m.y. or less.

\section{Limalok Guyot}

In the Marshall Islands region, the hiatus at Limalok Guyot is not well constrained because we do not know the age of the upper volcanic edifice. In addition, there is a 2-m.y. gap in age between the nannofossils and the carbonate deposits derived from the pioneering platform community for the centrally located Site 871 on Limalok Guyot. If there is a time gap between the marine flooding of the edifice and the inception of the platform at the other guyots, it is below the degree of fossil resolution between calcareous nannofossils and larger foraminifers. If one considers the radiometric age determined for hornblende crystals from volcaniclastics at the nearby basinal Site 462 as representative of the Limalok edifice age, then there is a large time gap of approximately $12 \mathrm{~m} . \mathrm{y}$. 


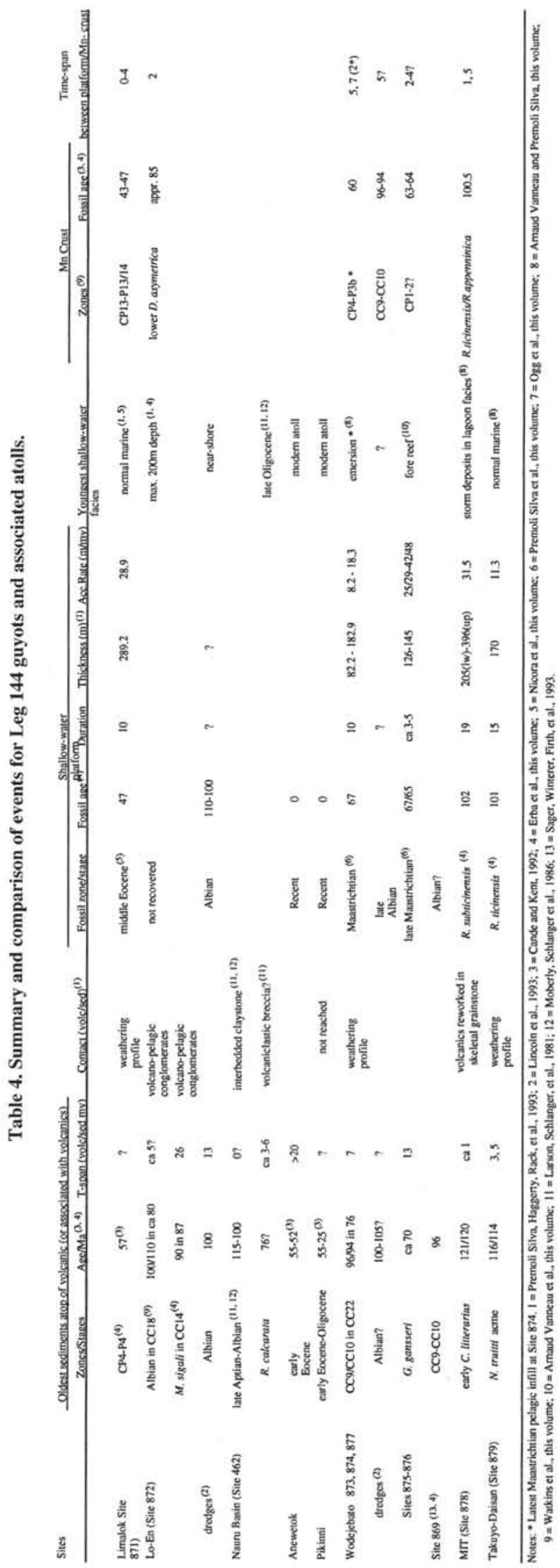

\section{Wodejebato Guyot}

For the three inner drill sites on Wodejebato Guyot (Sites 873, 874, and 877 ), $7 \mathrm{~m}$.y. passed before deposition of the recovered limestone. The transition to marine conditions at these three sites was in a relatively protected environment, compared to the outer ridge environment. In-situ weathering profiles that are at least $20-\mathrm{m}$ thick are preserved at the three inner drill sites, whereas the absence of a weathering profile and the presence of basalt pebbles in the lowermost marine sediments of the outer ridge sites implies higher energy conditions. As a consequence of these higher energy conditions at the outer perimeter ridge Sites 875 and 876 , it is not surprising that a longer hiatus, of 13 m.y., affected the outer sites.

The lower energy conditions at Site 877 aided the deposition of the carbonate sediment containing reworked Cenomanian nannofossils. These reworked calcareous nannofossils are at least $20 \mathrm{~m}$.y. older than the host sediment and indicate an older sediment history for the summit of this volcanic edifice. After the deposition of the calcareous nannofossils, but before the constructional subaerial lava flows formed the upper volcanic edifice of Wodejebato Guyot, approximately 11 to 13 m.y. passed. These Cenomanian nannofossils were probably related to the thick submarine volcaniclastic sequence that emerged before the deposition of the thin sequence of subaerial lava flows.

\section{Anewetak Atoll}

A large time gap in the rock record at the unconformity between the platform limestones and the edifice at Anewetak Atoll represents approximately $20 \mathrm{~m} . \mathrm{y}$. The paleontologic control is very poor because of the lack of age-diagnostic fossils in the lower section of that drill hole (Cole, 1957). There is an analogy between the outer ridge sites at Wodejebato Guyot and the drill site on Anewetak Atoll.

Although the Anewetak drill site was located on a carbonate island of the atoll, the drill hole passed through fore-reef debris at the base of the platform (Schlanger, 1963). The Anewetak drill site was positioned over the former fore-reef slope; the earliest shallow-water deposits on the Anewetak edifice are probably not represented at that location.

\section{MIT and Takuyo-Daisan Guyots}

On the basis of the radiometric date of the hawaiite lava flow and the first fossils deposited on MIT Guyot, there is a hiatus of 1 to $2 \mathrm{~m} . \mathrm{y}$. at the centrally located Site 878. A similar hiatus may have occurred on Takuyo-Daisan Guyot. An interval of 3 to 5 m.y. can be calculated as a gap in the record on the southern perimeter rim of Takuyo-Daisan Guyot at Site 879. This determination is more tentative because of the problematic radiometric age determined from dredged material (see Pringle and Duncan, this volume, for discussion of radiometric age).

The time gap between the age of the upper volcanic edifice and the inception of the carbonate platform is usually less than 7 m.y. for the Leg 144 guyots. This time interval can easily encompass the 1 to 3 m.y. suggested for the development of $12.5 \mathrm{~m}$ of soil at Site 871 on Limalok Guyot. None of the estimated time gaps refutes the contention that the soils on Limalok and Wodejebato guyots could take merely 1 to 3 m.y. to form.

If one assumes that a relatively low-lying volcanic island was weathering under lateritic conditions, the 1 to $3 \mathrm{~m}$.y. needed to form approximately $12.5-\mathrm{m}$-thick soil profiles may correspond to the time difference between the initial transgressive flooding of marine waters, as documented by the age of the calcareous nannofossils, and the transgressive deposition of shallow-water carbonate debris from seaward pioneering benthic communities. This would explain the 2-m.y. gap at Site 871 on Limalok Guyot between the age of the calcareous nannofossils and the age of the larger foraminifers. This time difference represents the geomorphical transition from a volcanic cone to a 
platform suitable for wider distribution of the shallow-water carbonate communities. At the other Leg 144 drill sites, the difference in age between the calcareous nannofossils and the larger foraminifers was not resolvable; the difference, if any, would be less than $3 \mathrm{~m}$.y.

At each of the inner or centrally located drill sites, the time gap between the age of the upper volcanic edifice and the appearance of the first age-diagnostic shallow-water organisms would be a function of the following factors: (1) the site's position on the weathering volcanic island; (2) the rate of transgressive flooding, including variations in global sea level, the rate of island subsidence, and the height and slopes of the volcanic island; (3) the rate of weathering and formation of clays and soils, including the rate of rainfall and of forest development; (4) the rate and extent of clays dispersed into the marine waters; and (5) the rate of offshore carbonate-community development.

\section{Pioneering Platform Communities}

The change from a marine flooded edifice, documented by nannofossils, to a carbonate platform, documented by skeletal debris of shallow-water macrofossils, is demonstrated by the deposition of marine-influenced clay overlain by argillaceous skeletal packstone. An offshore carbonate community contributes skeletal debris that is transported shoreward. The skeletal packstone helps to seal the clays and forms a substrate for further colonization by the pioneering-carbonate community. Abundant clays in suspension yielding greatly turbid marine waters would cause difficulty for some filter-feeding organisms; their filters would be clogged by too much fine sediment. Until the turbidity of the water is adequately diminished and the clay is sufficiently sealed by skeletal debris, filter-feeding and attachment by sessile organisms or algae would be hindered; hence, the potential delay before the pioneering community begins to flourish.

In general, the bases of the Leg 144 platforms contain pioneering communities that are primarily dominated by encrusting red algae (Premoli Silva, Haggerty, Rack, et al., 1993). The exceptions are the northern Leg 144 guyots, Takuyo-Daisan and MIT guyots.

At Site 878 on MIT Guyot, there was a sharp contact of claystone under poorly sorted grainstone that contains rare volcanic fragments. The carbonate grains contain common red algae and corals. A distinct pioneer community was lacking and the lithology contained some elements of a stabilizing community.

At Site 879 on Takuyo-Daisan Guyot, coral heads and intraclasts characterize the initial transgressive phase; red algae were not abundant. Gastropod rudstone containing nerinids, and calcareous sandstone composed of volcanic, carbonate, and coal grains, were also recovered. The presence of a carbonate contribution from rudists, gastropods, bivalves, and oncolites, along with the terrestrial component, indicates that this ecologic community represents a more restricted environment. These carbonate components were transported rather than formed in place as demonstrated by clastic nature of the deposits, and mixing of components from different environments including the presence of the calcareous nannofossilsand planktonic foraminifers. The basal platform deposition on Takuyo-Daisan Guyot is a transgressive marginal deposit.

Buchardt and Holmes (this volume) discuss in detail the initial transgressive phase on the volcanic edifices. They describe the lithofacies association for each site, and document the sulfur enrichment that is characteristic of the Leg 144 basal transgressive deposits.

\section{Comparison of Leg 144 with Leg 143 Platform Initiation}

The sea-level changes, climate, size of the exposed area and topographic relief of the volcanic edifice may influence the inception and development of the carbonate platform. The lowermost lithologies recovered from Allison and Resolution guyots, drilled on Leg 143, documents a different platform initiation process than was found on the Leg 144 guyots. The Leg 143 guyots from the Mid-Pacific Mountains have organic-rich clayey interbeds near the base of their thick carbon- ate platforms. The Leg 144 platforms do not have thick beds of clayey limestone nor are there abundant interbeds of organic-rich clays. At the Leg 144 sites, either the volcanic islands were more low-lying than those associated with the Leg 143 edifices, or the weathering and erosion of the Leg 144 edifices were more intense and rapid during the mid-Cretaceous, Late Cretaceous, and Paleocene than what occurred in the Mid-Pacific Mountains during the Early and Mid-Cretaceous time.

On Allison Guyot in Hole 865A, a 250-m-thick section of upper Albian clayey limestones and dolomitic limestones contains numerous laminated dark-colored clayey and organic-rich mudstone interbeds. These interbeds are several centimeters thick and increase in abundance downhole; these are interpreted as a lagoonal facies associated with restricted water exchange and periodic stagnation (Sager, Winterer, Firth, et al., 1993).

On Resolution Guyot in Hole 866A, a 966-m-thick Barremian to middle Albian clay-bearing sequence is composed of lagoonal-peritidal carbonate facies with three intercalated beds of oolitic limestone and numerous several-centimeter-thick organic-rich clayey interbeds and interbeds of clay-bearing algal laminites. The carbonate facies become partially to totally dolomitized downhole. The underlying unit is dolomitized oolitic-oncoidal grainstone that is barren of clay and directly overlies the basaltic edifice (Sager, Winterer, Firth, et al., 1993).

On both Leg 143 guyots, these lower carbonate platform sections contain a kaolinite-smectite assemblage (Murdmaa et al., this volume). The basaltic islands weathered subaerially to this mineral assemblage of immature lateritic soils forming in a warm tropical climate. This mineral assemblage was then eroded and deposited in nearby lagoons (Murdmaa et al., this volume).

Another clay-mineral assemblage was documented on Resolution Guyot as a hydromica assemblage between two zones of the kaolinite-smectite assemblage (Murdmaa et al., this volume). Pyrite and gypsum accompany the hydromica assemblage in the Barremian-Aptian carbonate platform. Murdmaa et al. (this volume) note that this assemblage coincides with a time of abnormal salinity and restricted water exchange with the open ocean, as the carbonate microfacies documents. They interpret the mineral assemblage to have formed insitu, within the organic-rich lagoonal sediments under poorly oxygenated or anoxic conditions. The absence of clay interbeds in the upper parts of the carbonate platforms is evidence of the final burial of the volcanic islands beneath the carbonates.

\section{PLATFORM EVOLUTION \\ General Observations}

Poor core recovery, typically $3 \%$ to $11 \%$, of the Leg 144 platform limestone strongly biases the interpreted reconstruction of the evolution of these carbonate platforms (see Appendix for discussion of drilling techniques attempted to improve core recovery). Use of the motor driven core barrel system and the resultant increase in recovery of up to $39 \%$ may have significantly enhanced our ability to interpret the evolution of the upper lagoonal section of the Wodejebato platform before its demise. This is one of the few locations that we have clear evidence of emersion before the demise of the platform.

Details of the stratigraphy and evolution of each platform are provided in chapters contained in this volume. In general, the Leg 144 central platform sites record fluctuations from open marine conditions to restricted conditions. These fluctuations were repetitive; some involved a temporary exposure of the platform. Bioconstructions were rarely encountered even in the platform margin sites. The topographic relief of the platform rims was not of well-developed reefs.

On Wodejebato Guyot the inner perimeter ridge contained two episodes of rudist patch reef development with skeletal debris forming shoals. At the location of Site 879, the southern rim of Takuyo-Dai- 
san Guyot is not a diagenetic relict, but was primarily formed from intermittent shoal development. The Leg 144 guyots have more characteristics in common with carbonate banks than with modern Pacific atolls.

\section{Platform Duration and Accumulation Rates}

Inferred ages and numeric estimates of the life span of the platforms, hiatuses, and platform accumulation rates, must be considered as an approximation. These values may be biased not only by the poor core recovery, but also by the uncertainties related to the poorly constrained ages of the shallow-water organisms or imprecise calibration of the time scale. The Gradstein et al. (1994) time scale was chosen as a standard to be used for this volume and Erba et al. (this volume) dedicated significant effort to integrate biostratigraphy, magnetostratigraphy, and strontium-isotope stratigraphy for the Cretaceous guyots drilled on Leg 144. Although problems may remain, the estimates we present in this section and Table 4 indicate the order of magnitude of the phenomena.

Of the platforms drilled during Leg 144, the platform on MIT Guyot shows the greatest longevity. Its lower and upper platform units, divided by a polymictic breccia, are more than 600 - $\mathrm{m}$ thick (excluding the breccia). The MIT platform grew for about 19 m.y. from the early Aptian to the late Albian. A life span of about 15 m.y. is estimated for the platform on Takuyo-Daisan Guyot, which appears to have started in the late Aptian and continued until the late Albian. According to Arnaud Vanneau and Premoli Silva (this volume), this platform ceased to grow slightly later than the platform on MIT Guyot. Curiously, the thickness is only $170 \mathrm{~m}$, about one-half the thickness of the upper platform on MIT Guyot for the same time span.

Two platforms drilled in the Marshall Islands region are of late Campanian-Maastrichtian age on Wodejebato Guyot, and mainly early to early-middle Eocene age on Limalok Guyot. Both have an average life span of $10 \mathrm{~m} . \mathrm{y}$. The shallow-water carbonate sequence on Limalok Guyot is approximately $290-\mathrm{m}$ thick. On Wodejebato Guyot, the platform sediment thickness varies from $82.2 \mathrm{~m}$ at the lagoonal setting (Site 873 ) to $183 \mathrm{~m}$ at inner ridge Site 877 , where the thickest bioconstruction lies. Intermediate sediment thicknesses were measured at the other three sites. Site 874 , has bioconstruction within the 163-m-thick platform, whereas the outer ridge Sites 875 and 876 have $126-\mathrm{m}$ and $145-\mathrm{m}$ thick carbonate sediment. The recovered limestone from the outer ridge sites spans a much shorter time interval, approximately 3-5 m.y., and therefore is, at the most, only onehalf the total life span of the Wodejebato platform.

These differences in platform thickness are expected to be reflected in the accumulation rate, which is not corrected for compaction. The MIT platform grew at a rate of approximately $31.5 \mathrm{~m} / \mathrm{m}$.y. and a comparable rate of about $29 \mathrm{~m} / \mathrm{m}$.y. is estimated for the Limalok platform. These accumulation rates may reflect the lack of major hiatuses or emersion episodes on these two platforms. Although the rough surface topography of MIT Guyot was suggested as a subaerial karst product, Haggerty and van Waasbergen (this volume) found little geochemical evidence to support $200 \mathrm{~m}$ of emergence of the guyot to generate this rough topography.

In contrast, much lower accumulation rates of $11.3 \mathrm{~m} / \mathrm{m} . \mathrm{y}$. and 8.2 $\mathrm{m} / \mathrm{m}$.y. are estimated for Takuyo-Daisan platform and the lagoonal Site 873 of Wodejebato Guyot, respectively. The inner ridge sites associated with bioconstruction on Wodejebato Guyot, yielded rates of $17 \mathrm{~m} / \mathrm{m} . \mathrm{y}$. at Site 874 and $18.3 \mathrm{~m} / \mathrm{m} . \mathrm{y}$. at Site 877 . Depending upon the inferred duration of 3 or 5 m.y., the accumulation rates for the outer ridge sites are 25 or $42 \mathrm{~m} / \mathrm{m}$.y. for Site 875 , and 29 or $48 \mathrm{~m} / \mathrm{m}$.y. for Site 876.

Lower accumulation rates, although not corrected for compaction, do appear to be related to the presence of one or more hiatuses in the sequences. At the lagoonal Site 873 on Wodejebato Guyot, the platform emerged at the end of sequence 2 (see Arnaud Vanneau et al., this volume) with formation of small karst cavities, and a second em- ersion truncated the top of the platform yielding the formation of rubble and smaller cavities. These two emersion episodes, although not as distinct, affected the platform at Sites 874 and 877 . The platform at Site 874 was more affected by these episodes than at Site 877; emergence accounts for the lack of an Omphalocyclus horizon and thinner limestone at Site 874 than at Site 877 . Sites 875 and 876 display a different evolution owing to their platform edge setting. Both lack the oldest sediments that occur only as reworked elements within younger Asterorbis-Sulcoperculina sands, which began to accumulate after the first emersion event and continued to accumulate later than the second emersion of the upper part of Wodejebato platform. Accumulation occurred longer at the northern Site 876 than at the southern Site 875. Arnaud Vanneau et al. (this volume) correlated these two emersion events on Wodejebato Guyot to Haq's (1991) 71 and $68 \mathrm{Ma}$ sea-level drops.

The situation at Takuyo-Daisan Guyot is far less constrained. The accumulation rate of $11 \mathrm{~m} / \mathrm{m}$.y., especially if compared to that of MIT Guyot, suggests that deposition was not continuous, or that the subsidence rate was very slow. Haggerty and van Waasbergen (this volume) also investigated the geochemical signature of the TakuyoDaisan carbonate platform for evidence of subaerial exposure as an explanation for its rough surface topography. No extensive geochemical signature was present to support subaerial exposure of over 100 $\mathrm{m}$ of the platform.

The high accumulation rates estimated for the platforms on MIT and Limalok guyots suggest that they lack major hiatuses or emersion episodes, or they had faster subsidence rates than the other Leg 144 guyots. From the sediment records at Sites 871 on Limalok Guyot and Site 878 on MIT Guyot, only fluctuations in sea level, as demonstrated by the occurrence of facies representing normal marine to restricted environments were found (Arnaud Vanneau and Premoli Silva; Nicora et al.; Ogg; all this volume). Oddly, the accumulation rates recorded in these platforms are comparable considering that (1) they are separated by a time span of more than 40 m.y., one mid-Cretaceous, the other Eocene, and (2) they are built from different organisms with potentially different growth rates. These platforms are more similar to carbonate banks rather than to atolls; if their subsidence rates are similar, this may explain the oddity.

\section{PLATFORM DEMISE}

At all the Leg 144 guyots, with the exception of Takuyo-Daisan Guyot, multiple generations of manganese-oxide hardground cap the carbonate platforms. Typically, the oldest generation of hardground is strongly phosphatized, followed by precipitation of manganeserich crust, and then in the final generation by the development of manganese-oxide dendrites. The time span between the inferred age of the youngest shallow-water sediment and the oldest pelagic sediment trapped in the hardgrounds averages 1 or $2 \mathrm{~m} . \mathrm{y}$. (Table 4).

An exception is Wodejebato Guyot where the oldest pelagic sediment within the hardgrounds is $5 \mathrm{~m} . \mathrm{y}$. younger than the shallow-water platform at inner Sites 873 and 877 . Nevertheless, at Site 874, also an inner ridge site, cavities are filled with pelagic sediments rich in planktonic foraminifers that probably are of latest Maastrichtian age. Evidently, before the end of the Maastrichtian the top of the carbonate platform was already under a pelagic regime at this site. This occurrence decreases the time span to 1 to $2 \mathrm{~m}$.y.; this is similar to the time gap at the other guyots (Premoli Silva, Haggerty, Rack, et al., 1993; Erba et al., this volume). The longer time gap between shallowwater facies and hardgrounds at Site 873 concurs with the conclusion that the second emersion event was more pronounced at Site 873 on the basis of sedimentological data.

Typically 1 to 2 m.y. after cessation of platform growth, all Leg 144 carbonate platforms, independent of their age, sank rapidly below the photic zone. Larson et al. (this volume) demonstrated that Pacific Plate motion carried the guyots into a location within the equatorial upwelling zone at the time of the carbonate- 
platform demise. In modern reef settings, nutrient-enriched waters inhibit the production of calcium carbonate by shallow-water organisms, whereas organisms that cause bioerosion increase in importance in that environment (Hallock and Schlager, 1986; Hallock, 1988).

The hypothesis that the demise of the platforms is related to plate migration toward the equatorial zone of increased upwelling (Larson et al., this volume) does not explain the cessation of the Albian "platforms" on Wodejebato and Lo-En guyots. These guyots did not reach the equatorial zone until Late Cretaceous time. In the literature, there is no major drop in sea level or strong cooling documented for the end of the Albian. There is still the question, why did so many platforms globally fail to survive beyond the Albian? See Larson et al. (this volume) for discussion of the Albian crisis.

Phosphatization of the oldest generation of pelagic sediments within the hardgrounds supports this interpretation that equatorial upwelling is responsible for demise of the carbonate platforms. According to Murdmaa et al. (this volume) and Bogdanov et al. (this volume), phosphatization can occur only in high-nutrient, low-oxygen conditions. Therefore, the presence of phosphatized pelagic sediments indicates that the guyots were still under the influence of the equatorial upwelling zone at the time the oldest pelagic sediments were trapped within the hardground. As the Leg 144 guyots continued to be carried northward by plate motion, they were removed from the equatorial upwelling zone, and consequently only manganese-oxide crusts were precipitated.

\section{SUMMARY}

Volcanic edifices in the northwest Pacific were constructed primarily in mid-Cretaceous time, in the Barremian, Aptian, and possibly Albian. Only the northernmost guyots drilled on Leg 144 were affected by this pulse of volcanism. This mid-Cretaceous volcanism extended until the Cenomanian for the Wodejebato Guyot area of the Marshall Islands, as documented by the radiometric date from Site 869.

The mid-Cretaceous pulse of volcanism was followed by a second episode, confined to the Marshall-Line Islands area, which apparently was produced by a smaller volume of magma than the first episode. Between the two episodes of volcanism, some edifices and plateaus remained elevated; their summits remained at water-depths compatible with hardground formation. Evidence for this interpretation is found in the drilling results from Lo-En Guyot, and dredge hauls from Wodejebato Guyot and the Line Islands.

Paleolatitudes, estimated from drill-core samples and plate reconstruction, support the hypothesis that during both pulses of volcanism, edifices formed over hotspots, which were located in the Southern Hemisphere. Migration of hotspots over time might explain the differences between plate reconstructions and seamount paleolatitudes estimated from the paleomagnetic data. Volcanic events in this portion of the Pacific were dated radiometrically.

Both volcanic pulses formed islands, which were forested and were weathered as long as $3 \mathrm{~m} . \mathrm{y}$. in a tropical-subtropical climate. The first marine sediments were deposited 2 to $7 \mathrm{~m}$.y. later on clays and weathered volcanics. Fore-reef slope and guyot-margin locations were affected by larger hiatuses, which were longer than $15 \mathrm{~m} . \mathrm{y}$. on Anewetak Atoll and 10 m.y. along the margins of Wodejebato Guyot. At Lo-En Guyot, taking into account dredge data, the time gap is approximately 2 to $7 \mathrm{~m}$.y. This is similar to hiatuses at other lagoonal or inner platform sites.

The growh duration of these carbonate platforms varies from 19 m.y. at MIT Guyot to 10 m.y. at Wodejebato and Limalok guyots. Takuyo-Daisan Guyot carries a platform with a 15 m.y. life span. Considering the longevity of Resolution Guyot in the Mid-Pacific Mountains, platforms growing in early mid-Cretaceous time re- mained under favorable growth conditions longer than the platforms growing in Late Cretaceous time.

The Aptian-Albian plate migration was partially westward, rather than northward as in Late Cretaceous time. This plate motion kept the mid-Cretaceous platforms in the tropics for a longer time, before they finally reached the critical latitude of equatorial upwelling where they died.

The demise of platforms is related to plate migration toward the equatorial zone of increased upwelling, where conditions favored bioerosion rather than bioproduction. Arrival probably was coupled with rises in sea level. The calculated paleolatitudes of the MIT, Takuyo-Daisan, Wodejebato, and Lo-En platforms at the time of their demise are in agreement with this hypothesis. Wodejebato and Limalok platforms were already close to the critical zone when the youngest platforms formed. This hypothesis does not explain the cessation of the Albian "platforms" on Wodejebato and Lo-En Guyot, which died far away from the equatorial zone.

The preservation of soils and weathering profiles are a new record of the guyot's history. Detection of sea-level changes on Leg 144 guyots was biased by poor core recovery, but drilling results on Wodejebato Guyot indicate that guyots are suitable areas where sea-level curves could be calibrated. Two emersions of Wodejebato platform were correlated to sea-level drops at 71 and $68 \mathrm{Ma}$. The pelagic regime prevailed at the summit of the guyots 1 to 2 m.y. after platform deposition ceased.

\section{ACKNOWLEDGMENTS}

The authors thank the Ocean Drilling Program for inviting them to be co-chief scientists. The authors warmly thank the Leg $144 \mathrm{Sci}-$ entific Party and the shipboard personnel of the JOIDES Resolution for all their hard work and unflagging optimism in the quest for Cretaceous reefs. The research was financially supported by a JOI-USSAC post-cruise science grant and an NSF-EPSCoR grant for support of midplate seamount diagenesis studies to $\mathrm{JAH}$, and a grant from Consiglio Nazionale della Ricerche to IPS. JAH thanks Kingston University, Surrey, England, where she wrote the initial draft of the manuscript while on sabbatical.

\section{REFERENCES $*$}

Bryan, P.C., Shoberg, T., Gordon, R.G., Petronotis, K.E., and Bergersen, D.D., 1993. A paleomagnetic pole and estimated age for Lo-En Guyot, Republic of the Marshall Islands. In Pringle, M.S., Sager, W.W., Sliter, W.V., and Stein, S. (Eds.), The Mesozoic Pacific: Geology, Tectonics, and Volcanism. Geophys. Monogr., Am. Geophys. Union, 77:387-400.

Chauvel, C., Hofmann, A.W., and Vidal, P., 1992. HIMU-EM: the French Polynesian connection. Earth Planet. Sci. Lett., 110:99-109.

Cole, W.S., 1957. Larger foraminifera from the Eniwetok atoll drill holes. Geol. Surv. Prof. Pap. U.S., 260-V:743-784.

Crough, S.T., 1978. Thermal origin of mid-plate hotspot swells. Geophys. J. R. Astron. Soc., 55:451-469.

Darwin, C., 1837. On certain areas of elevation and subsidence in the Pacific and Indian Oceans, as deduced from the study of coral formations. Proc. Geol. Soc. London, 2:552-554.

, 1842. The Structure and Distribution of Coral Reefs: London (Smith, Elder).

Davis, A.S., Pringle, M.S., Pickthorn, L.B.G., Clague, D.A., and Schwab, W.C., 1989. Petrology and age of alkalic lava from the Ratak Chain of the Marshall Islands. J. Geophys. Res., 94:5757-5774.

Detrick, R.S., and Crough, S.T., 1978. Island subsidence, hot spots, and lithospheric thinning. J. Geophys. Res., 83:1236-1244.

\footnotetext{
"Abbreviations for names of organizations and publications in ODP reference lists follow the style given in Chemical Abstracts Service Source Index (published by American Chemical Society).
} 
Duncan, R.A., and Clague, D.A., 1985. Pacific Plate motion recorded by linear volcanic chains. In Nairn, A.E.M., Stehli, F.G., and Uyeda, S. (Eds.), The Ocean Basins and Margins (Vol. 7A): The Pacific Ocean: New York (Plenum), 89-121.

Fischer, A.G., Heezen, B.C., et al., 1971. Init. Repts. DSDP, 6: Washington (U.S. Govt. Printing Office).

Gordon, R.G., and Cape, C., 1981. Cenozoic latitudinal shift of the Hawaiian hotspot and its implications for true polar wander. Earth Planet. Sci. Lett., 55:37-47.

Gradstein, F.M., Agterberg, F.P., Ogg, J.G, Hardenbol, J., Van Veen, P., Thierry, J., and Huang, Z., 1994. A Mesozoic time scale. J. Geophys. Res., 99:24051-24074

Haggerty, J.A., and Premoli-Silva, I., 1986. Ooids and shallow-water debris in Aptian-Albian sediments from the East Mariana Basin, Deep Sea Drilling Project Site 585: implications for the environment of formation of the ooids. In Moberly, R., Schlanger, S.O., et al., Init. Repts. DSDP, 89: Washington (U.S. Govt. Printing Office), 399-412.

Haggerty, J.A., Schlanger, S.O., and Premoli-Silva, I., 1982. Late Cretaceous and Eocene volcanism in the southern Line Islands and implications for hotspot theory. Geology, 10:433-437.

Hallock, P., 1988. The role of nutrient availability in bioersion: consequences to carbonate buildups, Palaeogeogr., Palaeoclimatol., Palaeoecol., 63:275-291.

Hallock, P., and Schlager, W., 1986. Nutrient excess and the demise of coral reefs and carbonate platforms, Palaios, 1:389-398.

Hamilton, E.L., 1956. Sunken islands of the Mid-Pacific Mountains. Mem.Geol. Soc. Am., 64.

Haq, B.U., 1991. Sequence stratigraphy, sea-level change, and significance for the deep sea. In Macdonald, D.I.M. (Ed.), Sedimentation, Tectonics and Eustasy: Sea Level Changes at Active Margins. Spec. Publ. Int. Assoc. Sedimentol., 12:3-39.

Heezen, B.C., Matthews, J.L., Catalano, R., Natland, J., Coogan, A., Tharp, M., and Rawson, M., 1973. Western Pacific guyots. In Heezen, B.C., MacGregor, I.D., et al., Init. Repts. DSDP, 20: Washington (U.S. Govt. Printing Office), 653-723.

Henderson, L.J., 1985.Motion of the Pacific Plate relative to the hotspots since the Jurassic and model of oceanic plateaus of the Farallon plate [Ph.D. dissert.]. Northwestern Univ., Evanston, IL.

Hess, H.H., 1946. Drowned ancient islands of the Pacific basin. Am. J. Sci., 244:772-791.

Larson, R.L., Lancelot, Y., et al., 1992. Proc. ODP, Sci. Results, 129: College Station, TX (Ocean Drilling Program).

Larson, R.L., Moberly, R., et al., 1975. Init. Repts. DSDP, 32: Washington (U.S. Govt. Printing Office).

Larson, R.L., and Sager, W.W., 1992. Skewness of magnetic anomalies M0 to M29 in the northwestern Pacific. In Larson, R.L., Lancelot, Y., et al., Proc. ODP, Sci. Results, 129: College Station, TX (Ocean Drilling Program), 471-481.

Larson, R.L., and Schlanger, S.O., 1981. Cretaceous volcanism and Jurassic magnetic anomalies in the Nauru Basin, western Pacific Ocean. Geology, 9:480-484.

Larson, R.L., Schlanger, S.O., et al., 1981. Init. Repts, DSDP, 61: Washington (U.S. Govt. Printing Office),

Lincoln, J.M., Pringle, M.S., and Premoli-Silva, I., 1993. Early and Late Cretaceous volcanism and reef-building in the Marshall Islands. In Pringle, M.S., Sager, W.W., Sliter, W.V., and Stein, S. (Eds.), The Mesozoic Pacific: Geology, Tectonics, and Volcanism. Geophys. Monogr., Am. Geophys. Union, 77:279-305.

Matthews, J.L., Heezen, B.C., Catalano, R., Coogan, A., Tharp, M., Natland, J., and Rawson, M., 1974. Cretaceous drowning of reefs on Mid-Pacific and Japanese guyots. Science, 184:462-464.

McNutt, M.K., and Fischer, K.M., 1987. The South Pacific superswell. In Keating, B.H., Fryer, P., Batiza, R., and Boehlert, G.W. (Eds.), Seamounts, Islands, and Atolls. Geophys. Monogr., Am. Geophys. Union, 43:25-34.

McNutt, M.K., Winterer, E.L., Sager, W.W., Natland, J.H., and Ito, G., 1990. The Darwin Rise: a Cretaceous superswell? Geophys. Res. Lett., 17:1101-1104.

Menard, H.W., 1958. Development of median elevations in ocean basins. Geol. Soc. Am. Bull., 69:1179-1186.

Menard, H.W., 1964. Marine Geology of the Pacific. New York (McGrawHill).

\footnotetext{
- 1984. Darwin Reprise, J. Geophys. Res., 89:9960-9968.
}

Moberly, R., Schlanger, S.O., et al., 1986. Init. Repts. DSDP, 89: Washington (U.S. Govt. Printing Office).

Morgan, W.J., 1972a. Deep mantle convection plumes and plate motions. AAPG Bull., 56:203-213.

1972b. Plate motions and deep mantle convection. Mem.-Geol. Soc. Am., 132:7-22.

Nakanishi, M., Tamaki, K., and Kobayashi, K., 1992. Magnetic anomaly lineations from Late Jurassic to Early Cretaceous in the west-central Pacific Ocean. Geophys. J. Int., 109:701-719.

Ogg, J.G., 1986. Paleolatitudes and magnetostratigraphy of Cretaceous and lower Tertiary sedimentary rocks, DSDP Site 585, Mariana Basin, western Central Pacific. In Moberly, R., Schlanger, S.O., Init. Repts. DSDP. 89: Washington (U.S. Govt. Printing Office), 629-645.

Ozima, M., Honda, M., and Saito, K., 1977. ${ }^{40} \mathrm{Ar} /{ }^{39} \mathrm{Ar}$ ages of guyots in the western Pacific and discussion of their evolution. Geophys. J. R. Astron. Soc., 51:475-485.

Ozima, M., Saito, K., and Takigami, Y., 1981. 40Ar-39Ar Geochronological studies on rocks drilled at Holes 462 and 462A, Deep Sea Drilling Project Leg 61. In Larson, R.L., Schlanger, S.O., et al., Init. Repts. DSDP, 61: Washington (U.S. Govt. Printing Office), 701-704.

Parsons, B., and Sclater, J.G., 1977. An analysis of the variation of ocean floor bathymetry and heat flow with age. J. Geophys. Res., 82:803-829.

Premoli Silva, I., Haggerty, J., Rack, F., et al., 1993. Proc. ODP, Init. Repts., 144: College Station, TX (Ocean Drilling Program).

Pringle, M.S., 1992. Radiometric ages of basaltic basement recovered at Sites 800, 801, and 802, Leg 129, western Pacific Ocean. In Larson, R.L., Lancelot, Y., et al., Proc. ODP, Sci. Results, 129: College Station, TX (Ocean Drilling Program), 389-404.

, 1993. Age progressive volcanism in the Musicians Seamounts: a test of the hot-spot hypothesis for the Late Cretaceous Pacific. In Pringle, M.S., Sager, W.W., Sliter, W.V., and Stein, S. (Eds.), The Mesozoic Pacific: Geology, Tectonics, and Volcanism. Geophys. Monogr., Am. Geophys. Union, 77:187-215.

Pringle, M.S., and Dalrymple, G.B., 1993. Geochronological constraints on a possible hot spot origin for Hess Rise and the Wentworth Seamount chain. In Pringle, M.S., Sager, W.W., Sliter, W.V., and Stein, S. (Eds.), The Mesozoic Pacific: Geology, Tectonics, and Volcanism. Geophys. Monogr., Amer. Geophys. Union, 77:263-277.

Sager, W.W., and Bleil, U., 1987. Latitudinal shift of Pacific hotspots during the late Cretaceous and early Tertiary. Nature, 326:488-490.

Sager, W.W., Duncan, R.A., and Handschumacher, D.W., 1993. Paleomagnetism of the Japanese and Marcus-Wake seamounts, Western Pacific Ocean. In Pringle, M.S., Sager, W.W., Sliter, W.V., and Stein, S. (Eds.), The Mesozoic Pacific: Geology, Tectonics, and Volcanism. Geophys. Monogr., Am. Geophys. Union, 77:401-435.

Sager, W.W., Winterer, E.L., Firth, J.V., et al., 1993. Proc. ODP, Init. Repts., 143: College Station, TX (Ocean Drilling Program).

Schlanger, S.O., 1963. Subsurface geology of Eniwetak Atoll. Geol. Surv. Prof. Pap. U.S., 260-BB:991-1066.

Schlanger, S.O., Garcia, M.O., Keating, B.H., Naughton, J.J., Sager, W.W., Haggerty, J.A., Philpotts, J.A., and Duncan, R.A., 1984. Geology and geochronology of the Line Islands. J. Geophys. Res., 89:11261-11272.

Schlanger, S.O., Jackson, E.D., et al., 1976. Init. Repts. DSDP, 33: Washington (U.S. Govt. Printing Office).

Schlanger, S.O., and Premoli Silva, I., 1981. Tectonic, volcanic, and paleogeographic implications of redeposited reef faunas of Late Cretaceous and Tertiary age from the Nauru Basin and the Line Islands. In Larson. R.L., Schlanger, S.O., et al., Init. Repts. DSDP, 61: Washington (U.S. Govt. Printing Office), 817-827.

Smith, W.H.F., Staudigel, H., Watts, A.B., and Pringle, M.S., 1989. The Magellan Seamounts: Early Cretaceous record of the south Pacific isotopic and thermal anomaly. J. Geophys. Res., 94:10501-10523.

Staudigel, H., Park, K.-H., Pringle, M.S., Rubenstone, J.L., Smith, W.H.F., and Zindler, A., 1991. The longevity of the South Pacific isotopic and thermal anomaly. Earth Planet. Sci. Lett., 102:24-44.

Turner, D.L., and Jarrard, R.D., 1982. K-Ar dating of the Cook-Austral island chain: a test of the hotspot hypothesis. J. Volcanol. Geotherm. Res., 12:187-220.

Wilson, J.T., 1963. A possible origin of the Hawaiian Islands. Can. J. Phys., 41:863-870.

Winterer, E.L., Ewing, J.I., et al., 1973. Init. Repts. DSDP, 17: Washington (U.S. Govt. Printing Office).

Winterer, E.L., Natland, J.H., van Waasbergen, R.J., Duncan, R.A., McNutt, M.K., Wolfe, C.J., Premoli Silva, I., Sager, W.W., and Sliter, W.V., 1993. 
1993. Cretaceous guyots in the Northwest Pacific: an overview of their geology and geophysics. In Pringle, M.S., Sager, W.W., Sliter, W.V., and Stein, S. (Eds.), The Mesozoic Pacific: Geology, Tectonics, and Volcanism. Geophys. Monogr., Am. Geophys. Union, 77:307-334.

Date of initial receipt: 1 August 1994

Date of acceptance: 4 January 1995

Ms 144SR-074

\section{APPENDIX}

\section{Core Recovery}

In addition to our using a roller cone bit with rotary core barrel (RCB drilling, traditionally used by the Deep Sea Drilling Program (DSDP) and the Ocean Drilling Program (ODP), we used alternative technology. The motordriven core barrel (MDCB) system, and a Geoset bit with the diamond core barrel (DCB) system were employed, as well as an anti-whirl polycrystallinediamond-compact (PDC) drag-type bit and a Syndax diamond coring bit with the RCB system. These techniques were used in an attempt to improve the core recovery of the platform limestones.

At Limalok Guyot, RCB coring in Hole $871 \mathrm{C}$ resulted in a very low average core recovery of $3.5 \%$ in the Cenozoic platform limestones and underlying clays. At Site 873 on Wodejebato Guyot, RCB coring in Hole 873A yielded a slightly higher average core recovery of $11.8 \%$ in the Cretaceous limestone platform. The upper $11 \mathrm{~m}$ of the platform was the most difficult to recover; average core recovery was only $2.5 \%$. We switched systems and usec the MDCB in Hole 873B for the same upper $11 \mathrm{~m}$ of the platform and recovery increased significantly to an average of $39.1 \%$. The major drawback for use of the MDCB on other Leg 144 guyots was time; it increased the length of time to drill the same 11-m interval as with RCB by a factor of 6 . Use of the MDCB and the resultant increase in recovery may have significantly enhanced our ability to interpret the evolution of the upper lagoonal section of the Wodejebato platform before its demise. This is one of the few locations for which we have clear evidence of emersion before the demise of the platform.

Drilling on the inner and outer ridge sites of Wodejebato Guyot provided additional challenges of essentially bare-rock spud-ins. Conventional rotary coring at the inner ridge sites yielded typically low core recovery. At Site 875 on the outer ridge, $\mathrm{RCB}$ coring in Hole $875 \mathrm{~B}$ yielded an average core recovery of $4.9 \%$ in the limestone. For Hole $875 \mathrm{C}$, we retrieved the pipe and changed from the rotary system to a DCB system that used a Geoset bit in an effort to improve recovery in the poorly cemented grainstone. This system and bit were used for the bare-rock spud-in and produced an average core recovery of $9.2 \%$ over the same interval drilled for Hole 875B, and an average core recovery of $13.2 \%$ for the complete hole of 14 cores of limestone and one core of basalt. At Site 876, also on the outer ridge, another effort was made to improve limestone recovery; the rotary core barrel bottom hole assembly was fitted with a drag-type "anti-whirl" PDC bit. Using the anti-whirl PDC, the average core recovery was $9.0 \%$ for 14 cores of this poorly cemented grainstone.

Our final effort to improve the core recovery was at Site 878 on MIT Guyot. Conventional rotary drilling of the first $200 \mathrm{~m}$ of platform limestone provided only an average core recovery of $2.29 \%$. We optimistically changed from a roller cone bit to a Syndax diamond coring bit; through the next $200 \mathrm{~m}$ of platform limestone the average core recovery was only $2.26 \%$.

Although a total of 20 holes was drilled at the 10 sites on Leg 144 and a significant effort was expended to improve the core recovery, none of the above techniques greatly enhanced our recovery. Before the expedition, we realized that core recovery might be low, therefore we endeavored to conduct an extensive and thorough logging program to aid our understanding of these guyots. The only sites where a logging program was not undertaken were the two outer ridge sites on Wodejebato Guyot where hole instability prevented logging. 